\title{
6.1 Internal protection/relocation/flight alternative as an aspect of refugee status determination
}

\author{
JAMES C. HATHAWAY* AND MICHELLE FOSTER
}

\section{Contents}

I. Introduction

II. Conceptual evolution of the IFA inquiry

III. The conceptual basis for analysis of internal alternatives to asylum

IV. The logic of a shift to 'internal protection alternative'

V. Steps for assessment of an internal protection alternative

A. Step 1: accessibility

B. Step 2: antidote

C. Step 3: no new risk of being persecuted, or of refoulement, to the region of origin

D. Step 4: minimum affirmative State protection available

\section{Introduction}

In many jurisdictions around the world, ${ }^{1}$ the possibility of an 'internal flight alternative' (IFA) (often referred to as 'internal relocation alternative')

* M. Kagan JD (Michigan, 2000) prepared a careful synthesis of backgtound materials upon which this study draws heavily. I am indebted to the insights on this issue provided by participants in the First University of Michigan Colloquium on Challenges in International Refugee Law in April 1999 in which the understanding of an 'internal protection alternative' relied upon here was refined; and to the contributors to the expert round table convened at San Remo, Italy, in Sept. 2001 to discuss this paper. This paper generally takes account of legal developments up to 1 Jan. 2002.

1 Such a test has no relevance in State Parties to the 1969 Organization of African Unity Convention Governing the Specific Aspects of Refugee Problems in Africa, 1001 UNTS 45, entered into force 20 June 1974. Under Art. I(2) of this regional arrangement, the definition of a refugee includes

every person who, owing to external aggression, occupation, foreign domination or events seriously disturbing public order in either part or the whole of his country of origin or nationality, is compelled to leave his place of habitual residence in order to seek refuge in another place outside his country of origin or nationality.

Emphasis added. 
is invoked to deny refugee status to persons at risk of being persecuted for a Convention ${ }^{2}$ reason in part, but not all, of their country of origin. ${ }^{3}$ In this, as in so many areas of refugee law and policy, the viability of a universal commitment to protection is challenged by divergence in State practice. The goals of this paper are therefore, first, briefly to review the origins and development of the practice of considering IFA as an aspect of the refugee status determination process; secondly, to identify key protection concerns in leading formulations of the IFA rule; and, thirdly, to propose relevant substantive and procedural standards which recognize the legal plausibility in some circumstances of considering internal protection alternatives, but which we believe avoid most of the protection pitfalls of current practice and doctrine.

For the sake of clarity, we refer to the 'best standard' approach proposed in this paper as the 'internal protection alternative'(IPA), a form of words which more precisely captures the essence of the permissible range of State discretion. In short, we believe that refugee status may not lawfully be denied simply because the asylum seeker ought first to have attempted to flee within his or her own State, nor even on the grounds that it would presently be possible for the applicant to secure 'safety' in the home country by relocating internally. Where an asylum seeker is shown to have access to true internal protection inside his or her own country, however, refugee status need not be recognized. This is because international refugee law is designed only to provide a back-up source of protection to seriously at-risk persons. Its purpose is not to displace the primary rule that individuals should look to their State of nationality for protection, but simply to provide a safety net in the event a State fails

21951 Convention Relating to the Status of Refugees, 189 UNTS 150 (hereinafter ' 1951 Convention').

3 This was the conclusion of the authors of a review of State practice in eighteen jurisdictions: see European Legal Network on Asylum (ELENA), 'The Application of the Concept of Internal Protection Alternative' (research paper, European Council on Refugees and Exiles (ECRE), Londo1998, updated 2000) (hereinafter 'ELENA Research Paper'), p. 65: 'To Lyy, however, thendon, doubt that the concept is firmly established in the nation. the 1951 Refugee Conve the 1951 Refugee Convention.' For example, the 1996 European Union's Joint Position interpreting the refugee definition includes reference to the internal protection alternative: see 'Joint Position Defined by the Council of the European Union on the Basis of Article K.3 of the European Union Treaty on the Harmonized Application of the Definition of the Term "Refugee" in Article 1 of the 1951 Geneva Convention Relating to the Status of Refugees', 4 March 1996, OJ 1996 L63/2 (hereinafter 'EU Joint Position'). Reference to the concept has also been reenty codified in US asylum law via amended regulations: see Code of Federal Regulation (CFR) Title 8, Immigration and Nationality Regulations, s. provide that the presurich provide that the presumption of entitlement to refugee status that flows from a showing of past persecution does not extend to those applicants who 'could avoid future persecution by relocating to another part of the applicant's country of nationality ... and under all the circumstances, it would be reasonable to expect the applicant to do so' (s. 208.13(1)(i)(B)). Further, the regulations provide that an applicant 'does not have a well-founded fear of persecution if the applicant could avoid persecution by relocating to another part of the applicants country if the tionality ... if under all the circumstances it would be reasonable to expect the applicantro of na(s. 208.13 (2)(C)(ii)). to meet its basic protective responsibilities. ${ }^{4}$ As observed by the Supreme Court of Canada:

The international community was meant to be a forum of second resort for the persecuted, a 'surrogate', approachable upon failure of local protection. The rationale upon which international refugee law rests is not simply the need to give shelter to those persecuted by the state, but, more widely, to provide refuge to those whose home state cannot or does not afford them protection from persecution. ${ }^{5}$

It follows logically that persons who face even egregious risks, but who can secure meaningful protection from their own government, are not eligible for 1951 Convention refugee status. Thus, courts in most countries have sensibly required asylum seekers to exhaust reasonable domestic protection possibilities as a prerequisite for the recognition of refugee status. Where, for example, the risk of being persecuted stems from actions of a deviant local authority or non-State entity (such as a paramilitary group, or vigilante gang) that can and will be effectively suppressed by the national government, there is no need for surrogate international protection.

The common scepticism of advocates about - and frequently outright rejection of $^{6}$ - the routine canvassing of internal protection alternatives is primarily a function of two factors. First, even though refugee law is generally understood as surrogate protection, State practice traditionally assumed that proof of a sufficiently serious risk in one part of the home country was all that was required. An individual ordinarily qualified for refugee status if there was a 'well-founded fear of being persecuted for reasons of race, religion, nationality, membership of a particular social group or political opinion"7 in the applicant's city or region of origin. Until the mid-1980s, there was no practice of routinely denying asylum on the grounds that protection against an acknowledged risk could be secured in another part of the applicant's State of origin.

To some extent, the traditional failure to explore the possibility of internal protection simply reflected the predisposition of Western asylum States to respond generously (for political and ideological reasons) to the then-dominant stream of refugees from communism arriving at their borders. With the arrival during

4 J. C. Hathaway, The Law of Refugee Status (Butterworths, Toronto, 1991) (hereinafter 'Hathaway, Refugee Status'), quotes at pp. 127-8, the French Conseil d'Etat in a decision of May 1983: '[T] he existence and the authority of the State are conceived and justified on the grounds that it is the means by which members of the national community are protected from aggression, whether at the hands of fellow citizens, or from forces external to the State' (unofficial translation).

5 Canada (Attomey-General) v. Ward, [1993] 2 SCR 689 at 716.

6 See e.g., B. Frelick, 'Down the Rabbit Hole: The Strange Logic of Internal Flight Alternative'

in World Refugee Survey (US Committee for Refugees, Washington DC, 1999), p. 22 (hereinafter 'Frelick').

71951 Convention, Art. $1 \mathrm{~A}(2)$ 
the 1980s of increasing numbers of refugees from countries that were politically, racially, and culturally 'different' from Western asylum countries, the historical openness of the developed world to refugee flows was replaced by a new commitment to exploit legal and other means to avoid the legal duty to admit refugees. ${ }^{8}$ The IFA inquiry emerged from this context and has played a major role in justifying negative assessments of refugee status.

In addition to concerns about its inauspicious origins, the propriety of considering internal alternatives to asylum has been called into question by the lack of clarity about why such considerations are an inherent part of the status determination process. Neither the United Nations High Commissioner for Refugees (UNHCR) nor most States have been consistent and clear in elaborating the legal basis for undertaking such an assessment. As the analysis in Sections II and III of this paper demonstrates, the apparently simple formulation of the IFA principle masks a huge range of variation between and even within States. The doctrinal confusion produces widely inconsistent results for refugee applicants and constitutes a source of unpredictability in refugee decision making.

These legitimate concerns notwithstanding, it must be conceded that the move to embrace IFA rules in recent years may also be explained by the growing number of persons seeking asylum since the late 1980 s who are fleeing largely regionalized threats (including many internal armed conflicts) rather than monolithic aggressor States. The changing nature of the circumstances precipitating flight may have allowed the consideration of the possibility of securing protection within one's own State in a way not previously available when the aggressor was usually a central government. If international refugee law is surrogate protection, and if national protection can (given the regionalized nature of many refugee-producing phenomena) be delivered in some, but not all, parts of the State of origin, then it follows logically that refugee law should be applied in a way that recognizes the extant realities and possibilities for individuals and groups to benefit from the protection of their own country, but which does not compromise access to asylum for those not in a position to avail themselves of national protection.

Defining this balance was the task set for the University of Michigan's first Colloquium on Challenges in International Refugee Law held in April 1999. Drawing on a framework prepared by the lead co-author of this paper in conjunction with the European Council on Refugees and Exiles (ECRE), a group of nine senior Michigan law students undertook a comprehensive review of the relevant jurisprudence of leading asylum countries. They synthesized their collective research by substantive sub-topics, and framed a series of critical legal and policy concerns. These were shared with a distinguished group of leading refugee law academics

8 See J. C. Hathaway, 'The Emerging Politics of Non-Entré', 91 Refugees, 1992, pp. 40-1; also published as 'L'émergence d'une politique de non-entrée', in Frontières da droit, Frontières des droits (ed. F. Julien-Laferrière, L'Harmattan, Paris, 1993), pp. 65-7. from around the world, each of whom contributed a brief response paper. The students and academics then worked collaboratively for three days in Ann Arbor, Michigan, on 9-11 April 1999, to refine an analytical framework for adjudicating internal protection concerns in consonance with general duties under the 1951 Convention. The result of that effort is the 'Michigan Guidelines on the Internal Protection Alternative'. ${ }^{9}$ The Guidelines have been shared with policymakers, decision makers, and advocates around the world, including with all members of the International Association of Refugee Law Judges. The first formal adoption of the Guidelines was by the New Zealand Refugee Status Appeals Authority, in its Decision No. $71684 / 99$ of 29 October $1999 .{ }^{10}$ The recommendations of this paper (detailed in Sections IV-VI) draw heavily on the Guidelines, though with some differences of emphasis.

In sum, whatever the precise reasons for its development and proliferation in the jurisprudence of many States, the aim of this paper is neither to engage in debates as to IFA's suspect origins, nor to argue for its rejection on this basis. Rather, this study undertakes a consideration of the legal basis for the asserted right to deny refugee status on internal protection grounds and seeks to articulate the legitimate scope of rules to govern its application in practice.

\section{Conceptual evolution of the IFA inquiry}

The precise origins of the IFA test are not clear. However, the source most often referred to as encapsulating the classic formulation of the principle is paragraph 91 of the UNHCR Handbook, which provides:

The fear of being persecuted need not always extend to the whole territory of the refugee's country of nationality. Thus in ethnic clashes or in cases of grave disturbances involving civil war conditions, persecution of a specific ethnic or national group may occur in only one part of the country. In such situations, a person will not be excluded from refugee status merely because he could have sought refuge in another part of the same country, if under all the circumstances it would not have been reasonable to expect him to do so. ${ }^{11}$

While there is little doubt that UNHCR hoped that paragraph 91 would deter States from excluding persons from refugee status 'merely' because they could have sought internal refuge, three salient features of this formulation have, in practice,

9 See J. C. Hathaway, 'The Michigan Guidelines on the Internal Protection Alternative', 21(1) Michigan Journal of International Law, 1999, p. 131 and available on http://www.refugeecaselaw. org/Refugee/guidelines.htm (hereinafter 'Michigan Guidelines').

10 [2000] INLR 165; this decision is also reported at www.refugee.org.nz/index.htm.

11 UNHCR, Handbook on Procedures and Criteria for Determining Refugee Status under the 1951 Convention and the 1967 Protocol Relating to the Status of Refugees (Geneva, 1979, re-edited 1992) (hereinafter 'Handbook'), at para. 91 (emphasis in original). 
frequently led to unwarranted denials of protection. First, the phrasing of paragraph 91 implies that exclusion from refugee status may be justified if the applicant failed to seek refuge in a part of the country of nationality, thus introducing a legitimate basis for the application of such a test. Secondly, it engages language that suggests a retrospective analysis, that is, an inquiry into whether the refugee 'could have sought refuge in another part of the same country' (emphasis added). Rather than focusing on the predicament that the applicant faces at the time of assessment, the Handbook's formulation appears to require an evaluation of the appropriateness of the applicant's pre-flight behaviour, a notion embodied in the shorthand phrase 'internal flight'. Thirdly, it introduces the concept of 'reasonableness' into the assessment, a phrase not derived from the 1951 Convention itself, nor elaborated upon in the Handbook. This formulation has a punitive connotation: if the failure to seek internal refuge is not adjudged to have been 'reasonable', then the person should be excluded from protection. This is of course difficult to reconcile with the explicit and closely circumscribed exclusion provisions contained in the 1951 Convention.

Although the Handbook was issued in 1979, the notion of IFA remained largely dormant until the mid-1980s when northern States began to explore legal options for restricting the application and scope of the 1951 Convention. IFA jurisprudence can be said to have begun in 1983-4 when the German Higher Administrative Court, in an approach endorsed by the Federal Constitutional Court in 1989, established a two-stage test that closely mirrored the framework set out in paragraph $91{ }^{12}$ Importantly, however, the Court did not adopt the retrospective quality of the Handbook's framework, but provided instead that an applicant could be denied protection if able to find safety in an alternative region in his or her home country, providing that the proposed region is free from other dangers or disadvantages that would be tantamount to persecution. The gist of this approach was soon embraced by leading common law jurisdictions, ${ }^{13}$ although the second element of the test was altered to incorporate the 'reasonableness' language of the UNHCR Handbook. As appellate courts began routinely to endorse the legitimacy of the IFA rule and

12 Judgment of 10 Nov. 1989, German Federal Constitutional Court, 2 BvR 403/84, 2 BvR 1501/84, Entscheidungssammlung zum Auslander- und Asylrecht (EZAR) 203 No. 5.

13 In two early cases, courts in the UK and the US adopted the IFA doctrine, although they did not engage in substantive analysis of its parameters. In R. v. Immigration Appeal Tribunal (IAT), exparte gested that a trade unionist from Ghana who faced perse (Queen's Bench Division) (QBD) sugdenied refugee status if he could live safely in a distant vilion in his previous home might be asylum because relocation would have forced him tistant village. The Court ultimately granted plication because relocation would have forced him to be separated from his wife (an early application of the reasonableness test). In Matter of Acosta, 19 I\&N Decisions 211, the US Board of Immigration Appeals (BIA) in 1985 rejected an appeal by a Salvadorean man partly Board of sis that 'the facts do not show that this threat existed in other cities in man partly on the bathat the respondent could have avoided persecution by moving to anos in El Salvador. It may be (at 235-6). to articulate its components, ${ }^{14}$ the incidence of reliance on IFA considerations increased significantly throughout the 1990 s.

The Handbook's formulation did not explicitly set out the textual basis for IFA analysis. However, further guidance as to the appropriate application of IFA analysis was provided by the UNHCR in March 1995 in an 'Information Note on Article 1 of the 1951 Convention', wherein it observed that the 'underlying assumption' for the application of the doctrine is 'a regionalized failure of the State to protect its citizens from persecution'. It explained:

Under such circumstances, it is assured that the State authorities are willing to protect a person against persecution by non-State agents, but they have been prevented, or otherwise are unable to assure, such protection in certain areas of the country. ${ }^{15}$

An important feature of the 1995 UNHCR formulation is that, despite continuing to use the language of 'internal flight alternative' and continuing to suggest at least a partly retrospective analysis, ${ }^{16}$ the UNHCR acknowledged that the proper focus of the inquiry is on the ability and/or willingness of the State of nationality to provide protection. Emphasis was placed on the need for an 'effective internal flight alternative', ${ }^{17}$ which would exist only where the proposed region is 'accessible in safety and durable in character' and where the conditions in the region correspond to major human rights instruments.

This protection-focused approach was even more clearly highlighted in an overview published later in the same year by the UNHCR Regional Bureau for

14 In 1990, the US Court of Appeals (Third Circuit) held that a refugee applicant's prima facie case for asylum must include an allegation that 'he would be persecuted beyond the local vicinity of his hometown': Etugh v. Immigration and Naturalization Service(INS), 921 F $2 d 36$ at 39. In 1991, the English High Court (QBD) quoted para. 91 verbatim, and relied upon it to reject an asylum application: R. v. Secretary of State for the Home Department, exparte Gunes, [1991] Imm AR 278. Also in 1991, the that the that the decision maker must be satisfied that 'there is no serious possibility of the claimant being persecuted in the part of the country in which it finds an IFA exists' and that the conditions in the IFA must be such 'that it would not be unreasonable, in all the circumstances, including those particular to the claimant, for him to seek refuge there': Rasaratnam v. Canada (Minister of Employment and Immigration), [1992] $1 \mathrm{FCJ} 706$ at 710. In 1994, the Full Court of the Federal Court of Australia handed down an influential decision in Randhawa v. Minister for Immigration Local Government and Ethnic Affairs, (1994) 124 ALR 265, 19 May 1994, in which it rejected athim by a Punjabi Sikh who feared Hindu militants would kill him for bengin on internal flight grounds.
ondu militants would kill him for belonging to the Akali Party on internal fight grounds.

15 UNHCR, 'Information Note on Article 1 of the 1951 Convention', March 1995 (hereinafter 'UNHCR 1995 Information Note'), at section 6.

16 Ibid., section 6 states: 'The possibility to find safety in othet parts of the country must have existed at the time of flight and continue to be available when the eligibility decision is taken and the return to the country of origin is implemented.' 
Europe. ${ }^{18}$ This document emphasized that ' $[p]$ rotection must actually be available for the person in question in the alternative location' and that the '[p]rotection 'reasonableness' as part of a protectinuing to endorse the Handbook's notion of time provided some concrete guidan-based IFA standard, UNHCR for the first ness' assessment. ${ }^{20}$ The reaso guidance on the essential elements of a 'reasonableprovision of basic civil, political and sost was said to include factors such as the tive circumstances of the applicant and ecio-economic human rights, the subjecitself'. ${ }^{21}$ Paper entitled 'Relocating Inis of the IFA concept is set out in a 1999 Position Asylum'. This document impernally as a Reasonable Alternative to Seeking papers (in which IFA was conceived as reses the conceptual thinking of the 1995 and capacity of the State of miling as relevant to the question of the willingness to be relevant to whether or no and

risk of persecution be made in cases where relocation is an issue is whether the can be successfully avoided by living experiences in one part of the country and if such a relocation is both posin another part of the country. If it can, this has a direct bearing on decisions related to reasonable for that individual, event that there is a part of the colated to the well-foundedness of the fear. In the for the asylum-seeker to live, the 'well fore it is both safe and reasonable The analysis about possible internal-sounded fear' criterion may not be fulfilled. holistic analysis of whether the asylum-seecer's can be a legitimate part of the well-founded. ${ }^{22}$

In addition to introducing the important conceptual shift from an analysis based sage that the to one based on well-founded fear, it is evident from the above passage that the 1999 Position Paper also engaged the language of 'relocation', reflectto a prospective anactice that had attempted to move away from a focus on 'flight' gested that two key points relocation alternatives. ${ }^{23}$ The 1999 Position Paper suga safe Iocation (an analysis of whether the propirst, whether the alternative site is

proped site is free of the relevant risk

tive Trends and Positions Taken by UNHCR, An Overview of Protection Issues in Western Europe: Legisla'UNHCR 1995 Overview') 19 Ibid., p. 32.20 Ibid.

22 UNHCR, 'Relocating It 21 lbid.

"Internal Flight Alternative" or "Reasonable Alternative to Seeking Asylum - The So-Called tion Paper'), at para. 9 (eme or "Relocation Principle"', 1999 (hereinafter 'UNHCR 1999 Post23 This approach has been particuladed).

the approach of the Michigan Guidelines (see above Zealand case law, although more recently survey of the approach of the New Zealand authorities, $n$. 9) has been explicitly adopted. For a Refugee Status Appeals Authority (RSAA), above n. 10 . and is generally habitable, stable, and accessible); and, secondly, whether it would be reasonable for this asylum seeker to seek safety in that location (which would include reference to a non-exhaustive list of factors set out in the Position Paper such as age, sex, health, family situation and relationships, language abilities, and social or other vulnerabilities). As will be explained below, basing an inquiry on these two notions is problematic. ${ }^{24}$ While UNHCR's important shift in understanding the correct 'textual home' for IFA analysis was supported by some State practice, it is nonetheless vital that we consider as a preliminary matter whether viewing the IFA inquiry as directed to the existence of a well-founded fear is justified as a matter of international law.

\section{The conceptual basis for analysis of internal alternatives to asylum}

The leading cases concerning the IFA principle have generally noted that the refugee definition in Article $1 \mathrm{~A}(2)$ of the 1951 Convention includes two key clauses: the well-founded fear clause ('owing to a well-founded fear of being persecuted for reasons of race, religion, nationality, membership of a particular social group or political opinion') and the protection clause ('is outside the country of his nationality and is unable, or owing to such fear, is unwilling to avail himself of the protection of that country'). While courts have frequently recognized that the clearest textual home for IFA is in the protection clause, ${ }^{25}$ the elements of the two clauses are sometimes conflated, with the result that IFA is said to be relevant to both prongs. For example, in Randhawa v. Minister for Immigration, Local Government and Ethnic Affairs, Black CJ explained:

Although it is true that the Convention definition of refugee does not refer to parts or regions of a country, that provides no warrant for construing the definition so that it would give refugee status to those who, although having a well-founded fear of persecution in their home region, could nevertheless avail themselves of the real protection of their country of nationality elsewhere within that country. The focus of the Convention definition is not upon the protection that the country of nationality might be able to provide in some particular region, but upon a more general notion of protection by that country. If it were otherwise, the anomalous situation would exist that the international community would be under an obligation to provide protection outside the borders of the country of nationality even though real protection could be found within those borders... In the present case the

24 See text below at nn. 85-111.

25 See e.g. Thirunavukkarasu v. Canada (Minister of Employment and Immigration), Canadian Federal Court of Appeal, [1994] 1 FC 589; Re S., Decision No. 11/91, New Zealand RSAA, 5 Sept. 1991; and Randhawa, above n. 14 
delegate correctly asked whether the appellant's fear was well-founded in relation to the country of nationality, not simply the region in which he lived. ${ }^{26}$

Clearly, the elements of 'well-founded fear' and 'protection' are to some extent intertwined. Indeed, in assessing whether a person has a well-founded fear of being persecuted in any region in the country, the decision maker, in addition to identifying the serious harm that may be inflicted for a Convention reason, must also scrutinize the State's ability and willingness effectively to respond to the risk ${ }^{27}$ As succinctly framed by the House of Lords in R. v. Immigration Appeal Tribunal, ex parte Shah and Islam, 'Persecution = Serious Harm + The Failure of State Protection'. ${ }^{28}$ If the State can effectively suppress the risk of serious harm in the claimant's place of origin, then the person does not have a well-founded fear of being persecuted.

It is crucial to understand, however, that the analysis shifts significantly once it has already been established that a person has a well-founded fear of being persecuted in his or her home area (region ' $A$ '), which of course implies that the State is unable or unwilling to protect the person in that region. ${ }^{29}$ Once this is established,

26 Randhawa, above n. 14 , pp. 268-9.

27 Hathaway, Refugee Status, above n. 4, p. 125. This formulation has been adopted in e.g. R. v. IAT 2 AC 629; Horvath v. Secretary of State for the Home Department House of Lords, [2000] 3 All, [1999] and Canada (Attorney-General) v. Ward, above n. 5. In Ministerfor Immigrations, [2000] 3 All ER 577; v. Khawar and Others, [2002] HCA 14, McHugh and Gummow JJ of took the view that the able took the view that the absence of domestic protection is not relevant to the meaning of 'persecution': paras. 66-72. However the other two judges comprising the majority disagreed. Kirby J explicitly affirmed the general common law view that failure of State protection is an essential element of 'being persecuted': paras. 106-18. Gleeson CJ also accepted that 'failure of the state to intervene to protect the victim [of persecution] may be relevant to whether the victim's fear continuing persecution is well-founded' (para. 29), and also appeared to accept the 'bifurcat of approach to persecution in stating that ' $[\mathrm{w}]$ here persecution consists of two elements, the criminal conduct of private citizens, and the toleration or cond or agents of the state, resulting in the with tled to expect, then the require ictims are entithed to expect, then the requirement that the persecution be for reason of one of the Convention grounds may be satisfied by the motivation of either the criminals or the state' (para. 31). Callinan $\mathrm{J}$ (in dissent) did not address the issue.

28 R. v. IAT and Another, ex parte Shah; Islam v. Secretary of State for the Home Department, above n. 27, per Lord Hoffmann. Lord Hoffmann explained, at p. 653, that the relevant persecution compre two elements:

First, there is the threat of violence to Mrs Islam by her husband and his political friends and to Mrs Shah by her husband. This is a personal affair, directed against them as individuals. Secondly, there is the inability or unwillingness of the State to do anything to protect them... These two elements have to be combined to constitut persecution within the meaning of the Convention.

$29 \mathrm{H}$. Storey has recently questioned the logic of what he refers to as the 'home test', that being the assumption that a refugee claim should in the first instance be assessed in relation to the applicant's place of origin. His essential point is that this approach unjustifiably imports a domicile test into refugee law, treating as legally irrelevant risks which might accrue in other parts it is neither logical nor realistic to find that the fact that the State can protect the person in some other region of the country (region ' $B$ ') means that she no longer has a well-founded fear of being persecuted in region $A .^{30}$ The well-founded fear of being persecuted in region $A$ has not been negated or removed by the provision of national protection in region $\mathrm{B}$, just as the risk would not be removed or negated by the availability of protection in a country of second nationality or in an asylum State. In all of these cases, the refugee continues to face a well-founded fear of being persecuted in region $A$ of his or her country of origin, but is able to avail him or herself of countervailing national protection. To hold otherwise is to construct a legal fiction fundamentally at odds with common sense.

Indeed, the text of the 1951 Convention itself envisages that the possibility of national protection will not necessarily allay the well-founded fear, as was well explained by Sedley LJ in the seminal Karanakaran decision:

[B]oth the special adjudicator and the tribunal failed to approach the Convention methodically. They treated the availability of internal [protection] as a reason for holding that the fear of persecution was not well-founded. There may possibly be countries where a fear of persecution, albeit genuine, can so readily be allayed in a particular case by moving to another part of the country that it can be said that the fear is either non-existent or not well-founded, or that it is not 'owing to' the fear that the applicant is here. But a clear limit is placed on this means of negating an asylum claim by the subsequent provision of the Article that the asylum-seeker must be, if not unable, then unwilling because of 'such fear' ex hypothesi his well-founded fear of persecution - to avail himself of his home

of the applicant's country of origin. 'Risk of this kind may be more or less real or more or less remote, but never purely academic': H. Storey, 'The Internal Flight/Protection Alternative - Key Issues', July 2001, at p. 15 (on file with authors). On balance, however, there seems little reason to depart from the accepted practice of focusing the inquiry on circumstances in the asylum son to depart from the acce gion may have an impact on the home region is in no sense foreclosed from adducing evidence to that effect. Since refugee status is forward-looking and requires only demonstration of a 'real chance' or 'serious possibility' of being persecuted, the fact that the harm has not already accrued in the home region is in no sense dispositive of the claim. On the other hand, if there is no such evidence, it is difficult to see why refugee status needs to be recognized. There is also a slippery slope argument to be made: any move away from an initial focus on the circumstances in the region most familiar to the applicant is likely to make it difficult for him or her to dischare the charge the shared duty of fact-finding (see Hacho logic of a requirement to demonstrate a country-wide risk of being persecuted (see text below at nn. 32-9).

30 According to G. de Moffarts, 'Refugee Status and the Internal Flight or Protection Alternative' (remarks delivered to the meeting of the International Association of Refugee Law Judges, "The 1951 Convention at Fifty: The Way Forward', Pretoria, South Africa, 12-15 July 2001) (hereinafter 'de Moffarts'): 'The Internal Flight Alternative is a consequence of the surrogate nature of international protection. The Convention definition itself limits refugee status to a person who can demonstrate inability or legitimate unwillingness to "avail himself of the protection of (the can demonstratei
home) state".' 
state's protection. If the simple availability of protection in some part of the provision would the foundation of the fear its causative effect, this provision would never be reached. ${ }^{31}$

Lest it be thought that this is merely a semantic debate, it is important to elucidate the negative practical consequences of anchoring IFA analysis in the wellfounded fear language of the 1951 Convention.

First, it has led some $S$ tates and courts to assert a requirement that the applicant establish 'country-wide persecution'. ${ }^{32}$ If an applicant's fear is said not to be well founded if it is objectively reasonable for him or her to reloar is said not to be well her own country, it is not illogical to insist that her to relocate to a part of his or well-founded fear in his or her own insist that the applicant establish not only a other city, town, and village in locality, but also that this fear extends to every US Board of Immd village in the country of origin. For example, in In Re C.A.L., the status on the basis, inter alia, that:

$[\mathrm{H}] \mathrm{e}$ has not provided any convincing evidence to suggest that his fear of persecution would exist throughout Guatemala. This Board has found that an alien seeking to meet the definition of a refugee must do more than show a well-founded fear of persecution in a particular place within a country. $\mathrm{He}$ must show that the threat of persecution exists for him country-wide. (emphasis
added)

31 Karanakaran v. Secretary of State for the Home Department, English Court of Appeal, [2000] 3 All

32 This approach has led to criticism from UNHCR: 'An ongoing practice was the restrictive in-
terpretation in some countries of various elements of the the requirement that applicants for refugee status of the refugee definition ... coupled with standard of proof. For example, a handful of countries tejectessively stringent burden and that, although they demonstrated a well-founded fer tejected asylum-seekers on the ground said fear extended to the whole of well-founded fear of persecution, they could not prove that 30 May 1991, p. 5. Ine whole of the territory of their country of origin': UN Doc. E/1991/85, argued that there. Interestingly, despite this official position, a UNHCR official has recentl tion being whether the as a three-step approach to IFA determination, with the first quently tion being whether the asylum-seeker has 'prove[n] a reasonable possibility of being quescuted throughout the country of origin'. If so, 'this proves that his orssibility of being perseH. Massey, 'Reasonableness Rescued? The Michigan Guidelines on the "Inear is well-founded': ternative" and UNHCR's Position on "Relocating Internally as an the "Internal Protection Aling Asylum"' (draft working manuscript dated Internally as a Reasonable Alternative to Seekwith authors).

33 Decision No. A70-684-022, BIA, 21 Feb. No. 3195, BIA, 15 Dec. 1992, wherein the Boa, at p. 5. See also, Matter of R., Interim Decision demonstrate a refugee without in which he in which the BIA held that 'in light of the country conditions .. Decision No. 3338, 20 Feb. 1998, operates in only a few areas of Peru, the respondents have ... [revealing] that the Shining Path that their fear of persecution from the Shining Path would provided any evidence to suggest also, US Regulations, above n. 3. The IAT in the UK would exist throughout that country'. See ing a rule incorporating para. 'a successful asylum claim require[s] the applicinto domestic regulations, which provide that country to which it was "pracis s] the applicant to establish persecution in all parts of the country to which it was "practical" to return': Dupovac, Decision persecution in all parts of the
Similarly, the US Court of Appeals for the Third Circuit affirmed the rejection of a Nigerian man's appeal, holding that the appellant had erred in his application before the Board of Immigration Appeals in failing to allege that he would be unable to live safely in another part of the country. The Court concluded:

[I]n this case the Board correctly decided Etugh had not made out a prima facie case for asylum. Etugh failed to allege he would be persecuted beyond the local vicinity of his hometown, Akirika... The scope of persecution Etugh alleges is not national and does not sustain his motion to reopen. ${ }^{34}$

This approach is not justified by the text of the 1951 Convention; rather it requires additional restrictive words to be read into the Convention definition such that it reads 'well-founded fear of being persecuted throughout the country of nationality'. ${ }^{35}$ Moreover, it imposes an extremely onerous burden on refugee applicants, a burden that is exacerbated by the many practical restrictions applicants often suffer in being able to obtain access to sufficiently precise and comprehensive country information. UNHCR has consistently criticized the country-wide persecution notion, ${ }^{36}$ describing this requirement as 'an impossible burden and one which is patently at odds with the refugee definition, the key criterion of which is that the asylum seeker show that he or she has a well-founded fear of being persecuted for a Convention reason ${ }^{37}$ Indeed, it is in direct conflict with the wellestablished approach to distributing the burden of proof in refugee cases, which UNHCR explains as follows:

[W] hile the burden of proof in principle rests on the applicant, the duty to ascertain and evaluate all the facts is shared between the applicant and the examiner. Indeed, in some cases, it may be for the examiner to use all the means at his disposal to produce the necessary evidence in support of the application. ${ }^{38}$

The 'country-wide persecution' approach also tends to produce a wide-ranging fishing expedition into potential alternative protection regions, and risks 'the conflation of issues' and a 'consequent lack of focused analysis'. ${ }^{39}$

34 Etugh v. INS, above n. 14.

35 See H. Storey, 'The Internal Flight Alternative Test: The Jurisprudence Re-examined', 10 International Joumal of Refugee Law, 1998, p. 499 at p. 524. Interestingly, this is the approach impliedly embraced by the Massey paper, above n. 32 , where he cites the 'Michigan Guidelines' as
a referring to a well-founded fear of being persecuted in one region or at least part of the country of origin. He then says that ' $[t]$ his phraseology begs the question whether, according to the Guidelines, proving a risk of persecution in one part of the country of origin actually proves that the asylum-seeker's fear is overall well-founded within the meaning of the refugee definition or establishes only a presumption to this effect': p. 4.

36 Concern with this notion can be traced back to at least the 1991 statement, above n. 32 .

37 UNHCR, 'Interpreting Article 1 of the 1951 Convention Relating to the Status of Refugees', April 2001 (hereinafter 'UNHCR 2001 Note on Interpreting Article 1'), at n. 28

38 Handbook, above n. 11, at para. 196.

39 Karanakaran v. Secretary of State for the Home Department, above n. 31, p. 476, per Sedley LJ. 
By contrast, analyzing the IFA as a protection alternative provides structure to the determination exercise and encourages a logical, methodical approach to the determination process. ${ }^{40}$ It is thus of considerable assistance to decision makers as well as to applicants. A protection-based understanding of IFA reinforces the fact that once the applicant has established a well-founded fear in one location, she is IFA analysis is und weight of the establishment of a prima facie case. In this way, the IFA analysis is understood as akin to an exclusion inquiry such that the evidentiary A second then on the party asserting an IFA to establish that it exists.

A second major practical concern is that conceiving the IFA issue as part of the ages decision into the existence of a well-founded fear of being persecuted encourgion by moving dis to pre-empt the analysis of well-founded fear in the first rethat it is wrong to usectly to the question of an IFA. Although UNHCR emphasizes or as an 'easy answ' IFA analysis to deny access to refugee status determination ${ }^{41}$ ating the issue as part of the cutl-fo bypass refugee status determination, ${ }^{42}$ situating the issue as part of the well-founded fear analysis tends to produce precisely tence of an IFA to dire many examples of decision makers relying upon the existo the an IFA to dismiss a claim without considering the conditions giving rise Review Tribunal and fear in the region of origin. ${ }^{43}$ For example, in Syan v. Refugee Review Tribunal and Another, the Australian Federal Court held that, 'having found termine whether the applicant hion of internal flight, it was not necessary to deConvention rea the applicant had a well-founded fear of persecution based on a Tribunal, which has ${ }^{44}$ This affirmed the existing practice of the Refugee Review without even consis dismissed a number of cases on the preliminary issue of IFA being persecuted ${ }^{45}$ simg the particulars of the applicant's well-founded fear of being persecuted. ${ }^{45}$ Similarly, in $R$. v. Secretary of State for the Home Department, exparte

40 The four steps in IPA assessment are set out in the text below at notes 112-85 and summarized in the Michigan Guidelines, above n. 9.

Note', above n. 15, at section 6, where it is empara. 2. See also, UNHCR '1995 Information sues involved, the concept of internal flight alternatived that '[d]ue to the complexity of the isof accelerated procedures'.

2 UNHCR, '1999 Position Paper

3 See e.g., the decision in Paper', above n. 22, at para. 18.

High Court (QBD) stated: 'It seems to me that if the [1996] Imm AR 603, whetein the English view, to which a person can be reture that if there is a safe place, from a Convention point unimportant a petson can be returned within his own country, it may in a number of cast of that coun that country from which he had come. The only relevance of whether thion reason in the part of secution for a Convention reason would be whether that risk whether there might be a risk of perit was shown to be unreasonable to require that the asyl risk established the question of whether country': p. 604. See also, R. v. IAT, exparte Mahendran, Englum seeker go back to the safe part of his 1999 (unreported decision on file with authors), a credibility finding, an appin an adjudicator errs on inquiry.

45 (1995) 61 FCR 284 at 288 , per Beazley J. the Tribunal has found that internal flight is a viable option ... the (RRT), 31 March 1999: 'As
Singh, the English High Court of Justice (Queen's Bench Division) held that 'the alternative flight option is a point that, on its own, would conclude this application against the applicant. ${ }^{46}$

This approach is a dangerous one, since an analysis of an IFA requires 'an indepth examination to establish whether the persecution faced by the applicant is clearly limited to a specific area and that effective protection is available in other parts of the country'. ${ }^{47}$ This concern is well exemplified in R. v. Secretary of State for the Home Department, ex parte Akar, in which a Kurdish woman claiming asylum on the basis that she and her family had supported the Kurdish separatist PKK was denied asylum by the adjudicator on IFA grounds alone and in the absence of an evaluation of all the evidence relating to the extent and nature of her well-founded fear of persecution. On an application for judicial review, the English High Court of Justice (Queen's Bench Division) dismissed her submissions, approving the use of IFA as a threshold inquiry as follows:

The third matter is that the Applicant contends that there were various errors of fact and that various items of background documentation were ignored. In my judgment, the Special Adjudicator was entitled, in the circumstances of this case, to focus as he did on the circumstances in Istanbul, on the existence of the two brothers in Istanbul, and to conclude from all the matters before him that there was no reason why this lady could not safely and reasonably live in Istanbul with them, particularly as the personal persecution of which she had experience related to life in the village. ${ }^{48}$

This decision must be open to question given the allegations of the applicant as to the basis of her well-founded fear. It is inherent in the notion of an internal alternative that the decision maker first understands the conditions to which the safe region is said to be a suitable alternative. On the one hand, by commencing the inquiry with an assessment of the well-founded fear in the region from which the person fled before moving to the protection question, the decision maker has a clear benchmark against which to assess the sufficiency of the internal protection available to the applicant. To locate the analysis within the well-founded fear criterion, on the other hand, allows the decision maker to avoid this careful analysis, and raises a substantial risk that legitimate claims will be dismissed following only cursory consideration of the relevant circumstances.

to determine whether the applicant otherwise satisfied the Convention definition of a refugee'; and Decision No. V98/08414, RRT, May 1999, in which it was held that '(i)t is not necessary for the Tribunal to determine whether there is a well-founded fear of persecution in part of a country before a relocation may be considered'

46 Decision No. CO/2696/98, English High Court (QBD), 3 March 1999, per Scott Baker J (unreported decision on file with authors).

47 Decision No. 70951/98, New Zealand RSAA, 5 Aug. 1998.

48 Decision No. CO/1789/99, English High Court (QBD), 17 Sept. 1999 (unreported decision on file with authors). 
In summary, to hold that the availability of alternative internal protection removes the well-founded fear of being persecuted involves a legal fiction which has concrete detrimental ramifications for refugee applicants. It is both more logical and linguistically satisfactory to view IFA analysis as relevant to the question whether national protection is available to counter the well-founded fear ${ }^{49}$ This language of the 1951 Convention naturally supports such a conceptualization of an IFA, which is moreover consistent with the well-established view of refugee law as surrogate protection..$^{50}$ Indeed, to collapse protection considerations into the wellfounded fear element makes the protection aspect of the definition largely super-
fluous.

The main objection ${ }^{51}$ that has been raised to an understanding of IFA rooted in the 1951 Convention's protection clause is that it impermissibly extends the notion

49 According to the EU Joint Position, above n. 3, at section. 8: Where it appears that persecution is clearly confined to a specific part of a country's
territory, it may be necessary, in order to check that the condition $1 \mathrm{~A}$ of the Geneva Convention has been fulfilled that the condition laid down in Article unable or, owing to such fear (of persecution), is unwillingt the person concerned 'is protection of that country', to ascertain whether inwilling to avail himself of the effective protection country, to ascertain whether the person concerned cannot find effective protection in another part of his own country, to which he may be reasonably
expected to move.

50 Hathaway, Refugee Status, above n. 4, p. 133. This understanding has been endorsed in Applicant A. and Another v. Minister for Immigration and Ethnic Affairs and Another, (1997) 190 ( where Dawson J held that it is a "well-accepted fact that international refuge CLR 225 at 248 , serve as a "substitute" for national protection where the latter was not provided duas meant to ination against persons on grounds of either civil or political status' crovided due to discrimWard, above n. 5, p. 731 per La Forest $\mathrm{J}$ : (IInternat or political status'; Canada (Attorney-General) v. stitute" for national protection where the latter was refugee law was meant to serve as a "subthe Home Department, aboveion where the latter was not provided'; Horvath v. Secretary of State for is to enable a person

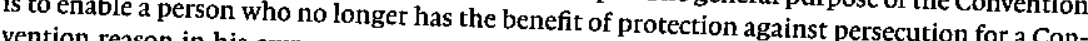
p. 589 peason in his own country to turn for protection to the international com for a Conp. 589 per Lord Lloyd: 'Thus the principle of surrogate protection finds its proper planity'; at second half of article $1 \mathrm{~A}(2)$. If there is a failure of protection by the country proper place in the cant will be unable to avail himself of that country's proten by the country of origin, the applitwo judges of the High Court of Australia have recently challenged at 594 per Lord Clyde. But notion of refugee law as surrogate protection 'add (s) a challenged this view, finding that the necessary distraction': Minister for Imotection 'add[s] a layer of complexity ... which is an unn. 27, at distraction': Minister for Immigration and Multicultural $\mathrm{Affairs} v$. Khawar and Others, anove

51 It has been argued the refugee definition which addresses the claims to refugee status made by in the portion of A stateless person need only show that he or she is unable or, owing to by stateless persons. to return to [the country of former habitual residencel'. If the 'protection fear, is unwilling the portion of the refugee definition applicable to pers. If the 'protection clause' contained in to engage in analysis of the internal protection alsersons with a nationality is the sole basis internal protection alternatives in relation to alte nossible to canvass sense. The right to interis the result may well make but only in perso in movement within a state does not inhere in all persons, Political pights, Political Rights, 999 UNTS 171, entered into force 23 March 1976 (hereinafter 'ICCPR'), anil 12(1). Indeed, the right to re-enter a State cannot even be asserted (hereinafter 'ICCPR'), at Art. of 'protection' beyond that intended by the framers of the 1951 Convention. It has been argued by Antonio Fortin that historical evidence suggests that the concept of 'protection' in the definition was intended to refer solely to diplomatic protection, rather than to internal national protection..$^{52}$ This leads him to conclude that, in light of the stipulation of the 1969 Vienna Convention on the Law of Treaties that 'special meaning shall be given to a term [of a treaty] if it is established that the parties so intended', ${ }^{53}$ the reference to 'protection' in the refugee definition should be read as 'diplomatic protection'. The argument is that refugee status is dependent upon whether or not a person can avail him or herself of the diplomatic protection of his or her country of nationality, the implication being that availability of this external protection obviates the need for surrogate protection, regardless of the risks that await an individual in the country of origin.

There are a number of significant problems with this analysis. First and most obviously, the extended term 'diplomatic protection' does not appear in the text of the 1951 Convention itself. Taking account of both the ordinary meaning of the

legal entitlement by non-citizens: ICCPR, Art. 12(4). Thus, because only a citizen is by definition both entitled to re-enter his or her country and to move and establish residence in any part of that State, there ate good grounds not to engage in an internal protection analysis with respect to stateless persons. Such an inquiry is predicated on a legal right to re-enter both the State and a given region thereof, neither of which may be presumed in the case of a stateless person.

52 A. Fortin, 'The Meaning of "Protection" in the Refugee Definition', 12(4) International Journal of . Refugee Law, 2000, p. 548 at p. 551 (hereinafter 'Fortin'). Two judges in the majority of a recent decision of the High Court of Australia, Minister for Immigration and Multicultural Affairs $\mathrm{v}$. Khawar and $\mathrm{Others,}$, above n. 27, have relied upon this historical interpretation. While Gleeson $\mathrm{CJ}$ accepted that the historical meaning of 'protection' was diplomatic or consular protection, he also considered that there is a broader sense in which the term 'protection' is used in the Convention (para. State for the Hom Deput inter State for the Home Department in which his Lordship explained that 'in the case of an allegation of persecution by non-state agents the failure of the state to provide the protection is nevertheless an essential element' (para. 19). Gleeson CJ explained that the 'broader sense of protection' may be of significance in interpreting various aspects of the Convention today, explaining: 'on the questions whether persecution is a threat, (which usually involves consideration of what has occurred in the past as a basis for looking at the future), and whether such persecution is by reason of one of the Convention grounds, and whether fear of persecution is well-founded, the obligaproction 'bifurcated' approach to the meaning of 'being persecuted' (para. 31), cited aboven. 27. Yet, while arguing that the historical meaning of protection was external protection, Kälin acknowledges that 'the very cornerstone of the regime of international refugee protection' is 'surrogate protection created by modern international refugee law': Kälin, below n. 59, p. 431. Moreover, Kälin recognizes that, "in international law, the "historical" interpretation of international treaties is only a supplementary means of determining the content of a treaty provision' and he provides (1) the protection clause an extended meaning that also covers internal protection' (ibid., at pp. $427-8$ ). This is consistent with the general approach to interpretation of the 1951 Convention. As Kirby J of the High Court of Australia has explained: '[l]ike the language itself, the Convention moves with the times': Chen Shi Hai v. Minister for Immigration and Multicultural Affairs, (2000) 201 CLR 293 at 312

531969 Vienna Convention on the Law of Treaties, 1155 UNTS 331, Art. 31(4). 
notion of 'protection ${ }^{54}$ and the ways in which the term 'protection' is used elsewhere in the 1951 Convention, the Fortin position is anomalous. In particular, the Preamble refers to the intention of the parties to 'revise and consolidate previous international agreements relating to the status of refugees and to extend the scope of and the protection afforded by such instruments', and to the importance of coordinated measures to facilitate UNHCR's task of 'supervising international conventions providing for the protection of refugees, ${ }^{55}$ Clearly, 'protection' as referred to in the Preamble cannot mean only 'diplomatic protection', since the Convention is concerned nearly exclusively with the provision of 'protection' understood in the sense of human rights protection.

Secondly, the isolated historical references that can be located do not justify the conclusion that the framers of the 1951 Convention clearly had this highly specialized understanding of 'protection' in mind. During the early phases of the drafting process, the goal had been to draft a single convention to govern the status of both refugees and stateless persons. Statements were therefore made during the early debates of the Ad Hoc Committee which appear to support Fortin's position, but only because they were addressed to the circumstances in which a stateless person (not a refugee) could be deemed not to require international protection. ${ }^{56}$ In the case of a stateless person - but not for a refugee - the willingness of a country's diplomatic personnel to enfranchise him or her by the provision of, for example,

54 Protection is defined as 'the act or an instance of protecting, the state of being protected'; while 'protect' is defined as 'keep safe; defend; guard': Concise Oxford Dictionary (9th edn, Oxford University Press, 1995). See also Lay Kon T $j i$ v. Minister for Immigration and Ethnic Afairs, (1998) 158 AL 681, where Finkelstein J of the Foderal Coun of Austalia surved tion' which comprise the enjoyment of 'effective natiolity' in tion' which comprise the enjoyment of 'effective nationality' in the context of an application fo refugee status by a dual national, noting that 'protection of the subject operates at two levels, viz., the domestic and the international' (at p. 690)

551951 Convention, Preamble.

56 The Ad Hoc Committee debated during its first session in Jan. and Feb. 1950 the question whether the 1951 Convention should deal with the problem of statelessness, ultimately deciding that the 1951 Convention should deal only with refugees. To the extent that the references cited are to discussions which occurred before the issue of statelessness was excluded from 1951 Convention, they are ou vention. For vention. For example, Fortin states that the Secretary-General 'postulated the need to establish an organization to provide to refugees the diplomatic protection that they lacked': Fortin, above n. 52, p. 560. However the supporting quote of the Secretary-General states: 'The conferment of a status is not sufficient in itself to regularize the standing of stateless persons and to bring them into the orbit of the law; they must also be linked to an independent organ which would to some extent make up for the absence of national protection and render them certain services which the authorities of a country of origin render to their nationals abroad'. Fortin, aboven. p. 560 (emphasis added) Similarly, Fortin argues that the Director-Geral of the Interen. 52 pefucentiona Refugee Organization recalled that refugees are 'unprotected aliens' insofar as they lack the protection which States grant to their nationals abroad, Fortín, above n. 52, p. 560 . However the actual quote cited by Fortin states: 'The refugee who enjoys no nationality is placed in an abnormal and inferior position which not only reduces his social value, but destroys his self-confidence' (emphasis added). a passport or entry visa might well be taken as indicative of a resolution to that person's dilemma, and hence logically inform the question of whether international protection is required. It is striking that once the decision to draft a separate convention on statelessness was made, there were only a few references made to the legal significance of 'diplomatic protection, ${ }^{57}$ and in fact very little discussion dedicated to the meaning of the 'protection' aspect of the definition at all. ${ }^{58}$ There is simpiy too little historical evidence ${ }^{59}$ to justify the conclusion that the authors of the 1951 Convention "specifically assigned to the term "protection" the special meaning of "diplomatic protection"'. ${ }^{60}$ Moreover, it is possible to locate references in the travaux préparatoires that support a flexible and open-ended definition of 'protection'. For example, in discussing the proposed Article 1C(3), Mr Hoare, the delegate of the United Kingdom, argued that 'it would be better to say "enjoys the protection of the country of his new nationality", for that would leave the State concerned to decide whether the refugee in fact enjoyed such protection, and how the phrase should be interpreted'. ${ }^{61}$

Thirdly, even if it were somehow shown that the special meaning of 'diplomatic protection' should inform the 1951 Convention's general references to 'protection', the Fortin view misinterprets the notion of diplomatic protection under international law. The well-established meaning of 'diplomatic protection' in international law is that it is 'action taken by a State against another State in respect of an injury to the person or property of a national caused by an internationally wrongful act or omission attributable to the latter State' ${ }^{62}$ This is a considerably narrower

57 Fortin cites the views of the US representative, Mr Henkin, who viewed protection as a 'term of art' (Fortín, above n. 52, p. 562), as well as the less direct statements by the Acting President of the Conference of Plenipotentiaries, Mr Humphrey (p. 563), and the representative of Israel, Mr Robinson (p. 561).

58 It is clear from reading the travaux préparatoires that the important and controversial issues in relation to Art. 1 were the temporal and geographical restrictions imposed in the 1951 Convention and the issue of how closely to define the Convention grounds. There was no extensive discussion of the meaning of 'protection'.

59 Apart from the three quotes from the travatix referred to above at $\mathrm{n}$. 56 , Fortin bases his assertions largely on secondary sources. W. Kälin, also a proponent of the view that the historical meaning of protection was 'diplomatic protection', makes reference to the record of the Ad Hoc Committee in which it is stated that 'unable' referred to refugees possessing a nationality who are refused passports 'or other protection by their own government', W. Kälin, 'Non-State Agents of Persecution and the Inability of the State to Protect', 15 Georgetown Immigration Law Journal, 2001, p. 415 at p. 425 . Yet this reference hardly seems dispositive, since the reference to 'other protection' is clearly open-ended.

60 Fortin, above n. 52, p. 551.

61 UN General Assembly, 'Summary Record of the Twenty-Third Meeting Held at the Palais des Nations, Geneva, on Monday, 16 July 1951', UN doc. A/Conf.2/SR.23, p. 19.

62 See J. Dugard, Special Rapporteur, 'First Report on Diplomatic Protection', 52nd Session of the International Law Commission (ILC), UN doc. A/CN.4/506, 7 March 2000, at Art. 1. It is important to note that this Article is not an example of progressive development on the part of the ILC, but rather a codification of existing international law: see M. Bennouna, Special Rapporteur, 'Preliminary Report on Diplomatic Protection', 50th Session of the ILC, 
concept than that advocated by proponents of the 'protection equals diplomatic protection' view in the refugee context. The precise outer parameters of the constructed notion of diplomatic protection are not clear, although it is said to include the provision of administrative assistance such as the issuance of passports and other documents. Thus, not only do proponents of this view seek to read additional words into the Convention text, but they also substitute the precise and well-established understanding of the term created by the addition of these words with a modified and expanded version of this term of art in international law. ${ }^{63}$ This analysis simply cannot be maintained as a matter of treaty interpretation.

Fourthly, it is difficult to justify the 'diplomatic protection' interpretation as being consistent with the object and purpose of the 1951 Convention (a primary requirement of treaty interpretation), since its relevance to refugee status is not clear. As the right to exercise diplomatic protection is a wholly discretionary right belonging to the State, which is exercised to ensure that international laws are observed, ${ }^{64}$

UN doc. A/CN.4/484, 4 Feb. 1998, at para. 5. The most frequently cited case as authority for the well-established narrow definition of diplomatic protection in international law is Mavrommatis Palestine Concessions, Permanent Court of International Justice, Series A, No. 2, 30 Aug. 1924.

63 See Report of the ILC on the Work of its 49th Session, 12 May-18 July 1997, UN doc. A/52/10, at para. 178, where 'diplomatic protection' is described as a 'term of art' within the meaning set out in Mavrommatis, above n. 62. Yet Fortin, above n. 52, p. 554, argues:

It is generally agreed that, in addition to what has been described above [i.e. the true meaning of diplomatic protection], it encompasses certain actions that diplomatic and consular representatives may undertake in order to ensure better standards of treatment for the nationals of the country abroad, as well as the provision of so-called 'administrative assistance' to nationals abroad, meaning the issuance and

authentication of certificates, the issuance and renewal of passports and so forth.

There is no case law cited in support of the general agreement adverted to and the position is entirely at odds with the work of the ILC in this area. Fortín quotes an ILC report in support of his proposition; however the passage cited contradicts rather than supports his understanding of the meaning of 'diplomatic protection'. The passage quoted distinguishes between diplomatic protection 'properly so called, that is to say a formal claim made by a State in respect of an inutic one of its nationals which has not been tedressed through lo other diplomatic functions: other diplome Report of the ILC on the Work of its 49th Session, and is followed, in the ILC report, by a clear exposition of the natrow basis of diplomatic protection at international law: ibid., paras. 182-3. Indeed, in a subsequent report (Bennouna, above n. 62), the ILC noted: 'However, as noted by the Commission's working group, diplomatic protection strictu sensu is very different from the diplomatic mission or consular functions exercised by the sending State in order to assist its nationals or protect their interests in the receiving country' (at para 12).

Case, above n. 62, p. 12, where the Permanent Court of

It is an elementary principle of international law that a State is entitled to protect its subjects, when injured by acts contrary to international law committed by another State, from whom they have been unable to obtain satisfaction through the ordinary channels. By taking have been unable to obtain satisfaction through the ordinary channels. By taking up the case of one of its subjects and by resorting to diplomatic action or international judicial proceedings on his behalf, a State is in reality asserting its own rights - its right to ensure, in the person of its subjects, respect for the rules of international law. the decision of a State not to exercise diplomatic protection in relation to one of its nationals may have no bearing whatever on whether it could provide internal protection to the national. ${ }^{65}$ Rather, the decision whether or not to exercise diplomatic protection may reflect considerations of domestic or international politics that have no relationship to the ability of a State to protect its nationals internally. Thus, arguing that refugee status should turn upon the willingness or ability of the State to exercise diplomatic protection is illogical.

Fifthly, the availability of diplomatic protection does not necessarily bear any relationship whatsoever to the question of whether a State would wish to protect an individual against a well-founded fear of being persecuted. ${ }^{66}$ As Grahl-Madsen has succinctly explained:

It is entirely conceivable that a person may have well-founded fear of being persecuted upon his eventual return to the country of his nationality, yet he may have nothing to fear at the hands of the members of the foreign service of that country. The Convention would, in fact, be rendered meaningless if a person's claim to refugee status should depend on whether the diplomats or

As Bennouna, above n. 62 , at para. 19, explained:

In the traditional view [of diplomatic protection], the endorsement of a claim is a discretionary right of the State of nationality, which has complete latitude to accept or reject it 'without being required to justify its decision in any way whatsoever' e.g., without having to rely on the unfounded nature of the claim or on its foreign policy needs.

See also Dugard, above n. 62, ILC draft Article 3 and commentary at paras. 61-74. While the traditional view that diplomatic protection is a right of the State has been subject to criticism in recent years, it clearly remains the position in international law (ibid.)

65 This point was recognized by the Federal Court of Australia in Lay Kon Tji v. Minister for Immigration and Ethnic Affairs, above n. 54. In that case, Finkelstein J found that the potential inability of Portugal to provide diplomatic protection would not render it a State that is incapable of providing effective nationality such that it ought not to be deemed a country of second nationality pursuant to $\mathrm{Art} .1 \mathrm{~A}(2)$ of the 1951 Convention. This was because: ' $\mathrm{A}]$ national does not have a right to diplomatic protection from his or her State; that is, it is not a right of nationality. Diplomatic protection is the tight of the State to intervene on behalf of its nationals. The State has complete discretion whether to exercise this right and is not in any way bound to protect its nationals discretion wheth (at p. 693). See also, N. Nathwami "The Purpose of Asy Law, 2000, p. 354 at p. 359.

66 Indeed, this point is acknowledged by one of the proponents of the historical view of protection as 'diplomatic protection'

Conceptually, it is conceivable that a victim of persecution by non-state actors [which] cannot be stopped by the authorities may be forced to leave his or her country of origin but is able and willing to live abroad as an alien enjoying full external protection by his country. In such cases he or she would be in a situation similar to that of many migrants who are forced to go abroad in order to survive economically but are not in need of surrogate international protection.

Kälin, above n. 59, p. 426 
consular officers of his home country were likely to persecute him should he ever ask them for protection or assistance. ${ }^{67}$

Indeed, the diplomatic protection thesis allows the unilateral action of the State of nationality to remove the refugee's right to protection, a position irreconcilable with Article $1 C(1)$ which denies status only where the refugee voluntary re-avails him or herself of the protection by the State of nationality. ${ }^{68}$

Sixthly, the 1969 Vienna Convention specifically directs attention to subsequent practice in the application of a treaty which establishes agreement of the parties regarding its interpretation. Accordingly, reference to the leading cases in common law jurisdictions reveals that the narrow 'diplomatic protection' approach is inconsistent with a growing body of jurisprudence that recognizes that the object of the 1951 Convention is 'surely to afford protection and fair treatment to those for whom neither is available in their own country'. ${ }^{69}$ Whatever the historical origins of the protection clause, the concept of refugee law as providing surrogate or substitute protection is now accepted by most senior courts in the common law world, having been described as a 'well-accepted fact'. ${ }^{70}$ In the specific context of IFA analysis, there is also growing consensus that the 'protection' aspect of the definition is the appropriate place for situating the analysis of internal alternative national protection. As framed by Lee J of the Australian Federal Court:

To put it [the IPA question] in the terms of the Convention definition, if the applicant is outside the country of his nationality because of a well-founded fear of persecution, is he unable to avail himself of the protection of that country? That ... question ... involves consideration of the applicant's circumstances as they are now and his ability to return to his country of nationality and obtain protection. ${ }^{71}$

67 A. Grahl-Madsen, The Status of Refugees in International Law (A. W. Sijthoff, Leyden, 1966), vol. I, p. 257.

68 This is because diplomatic protection is not a right of the individual; therefore the individual 'cannot renounce it effectively' (Nathwami, above n. 65, p. 358). Rather, the right to exercise diplomatic protection is a right of the State: see above n. 64. Nathwami explains: 'If diplomatic protection were a crucial criterion for determining refugee status, the State of origin might gran diplomatic protection over the head of the refugee and, thus, obstruct the grant of asylum to the tefugee' (ibid.). While it is true that the kinds of considerations normally referred to in relation to Art. $1 \mathrm{C}(1)$ relate to 'external' protection (such as consular assistance), this does not suggest that protection means external protection alone. As G.S. Goodwin-Gill argues, there is no reason why protection cannot refer both to diplomatic protection and internal protection, depending on the context: G. S. Goodwin-Gill, The Refugee in International Law (2nd edn, Clarendon, Oxford, 1996) context: G. S. Good

69 R. v. Secretary of State for the Home Department, ex parte Sivakumaran, House of Lords, [1988] 1 All ER 193 at 196 per Lord Keith of Kinkel. See Vienna Convention, above n. 53, Art. 31(3)(b).

70 Applicant A. and Another v. Minister for Immigration and Ethnic Affairs and Another, above n. 50, per Dawson J. See generally the cases cited above in nn. 50 and 52.

71 Al-Amidi v. Minister for Immigration and Multicultural Affairs, (2000) 177 ALR 506 at 510. See also, Randhawa v. Minister for Immigration, Local Government and Ethnic Affairs, above n. 14, pp. 268-9; Butler v. Attorney-General, New Zealand Court of Appeal, [1999] NZAR 205; Karanakaran v.
Finally, the assertion that 'protection' should be understood as 'diplomatic protection' is also out of step with most ${ }^{72}$ contemporary pronouncements of UNHCR as manifested in its official documents, ${ }^{73}$ outreach materials, ${ }^{74}$ and interventions

Secretary of Statefor the Home Department, above n. 31; Adan v. Secretary of State for the Home Department, English Court of Appeal, [1997] 2 All ER 723; Islam v. Minister for Immigration and Multicultural Affairs, Federal Court of Australia, (2000) 171 ALR 267. The same view is adopted in the EU Joint Position, above n. 3 , at section 8 (cited above n. 49).

72 In one recent statement, UNHCR has unfortunately endorsed the diplomatic protection approach on the basis that ' $\mathrm{u}$ |nwillingness to avail oneself of this external [diplomatic] protection is understood to mean unwillingness to expose oneself to the possibility of being returned to the is unders of nationality where the feared persecution could occur': UNHCR, '2001 Note on Intercountry of nationality where the feared persecution could oceurilability of diplomatic protection preting Article 1', above n. 37 , at para. 35 . Yet because the availability of diplomatic protection
similarly has no bearing on the question of removeability, this explanation for the 'diplomatic

protection' position does not withstand scrutiny.
It is argued by Fortin, above n. 52 , and more recently by Massey, above n. 32, p. 4 (relying on Fortin) that the diplomatic protection thesis is the UNHCR's 'long-held understanding' of the meaning of protection, and that any inconsistency with this approach was 'temporary': Massey, meave 3 . above 11 , n. 11, takes a fexible appreach agents of persecution strongly suggests that protection means internal protection: 'Where serious discriminatory or other offensive acts are committed by the local populace, they can be considered as persecution if they are knowingly tolerated by the authorities, or if the authorities refuse, or prove unable, to offer effective protection.' The protection phrase is specifically considered at paras. 97-100, and while 'external' protection is envisaged as being encompassed within the phrase, it is by no means said to be confined to external protection. For example, para. 99 states:

What constitutes a refusal of protection must be determined according to the circumstances of the case. If it appears that the applicant has been denied services

(e.g., refusal of a national passport or extension of its validity, or denial of admittance to the home territory) normally accorded to his co-nationals, this may constitute a refusal of protection within the definition.

To the same effect, see UNHCR, '1995 Information Note', above n. 15, at section 5, in which '19g5 in extension UNHCR state: The esential issue in establion of international protection is the fact of an absence of national protection against persecution, whether or not this deficiency can be attributed to an affirmative intention to harm on the part of the State.' In its 1995 Overview, above n. 18, pp. 28-9, UNHCR stated that:

the decisive criterion for refugee status is that an individual having a well-founded fear of persecution is unable or, owing to such fear, is unwilling to avail himself of the protection of his country of origin. Thus the essential element for the extension of international protection is the absence of national protection against persecution, irrespective of whether this absence can be attributed to an affirmative intention to harm on the part of the state. A situation in which the state is incapable of providing national protection gainst persecution by non-government agents clearly renders the individual unable to avail himself of the protection of his country of origin.

Thus, at least from 1979 to 1995 , UNHCR appears to have favoured a broader understanding of 'protection'.

74 For example, in a segment answering 'frequently asked questions' on the UNHCR website, the question, 'What is protection?' is answered as follows:

Governments normally protect their citizens, assuring them their right to life, freedom and physical security. When governments are unable or unwilling to do so and 
in domestic adjudication. ${ }^{75}$ In all these contexts, UNHCR insists that 'protection' in the Convention sense corresponds with the ordinary meaning of that word, not with 'diplomatic protection'. As explained in the 1994 Note on International Protection submitted by the High Commissioner to the Executive Committee:

Unlike most other people who leave their country, refugees seek admission to another country not out of choice but out of absolute necessity, to escape threats to their most fundamental human rights from which the authorities of their home country cannot or will not protect them. Left unprotected by their own Government, refugees must seek the protection that every human being requires from the authorities of a country of refuge and from the international community. It is this vital need for international protection that most clearly distinguishes refugees from other aliens. ${ }^{76}$

In sum, there is simply no compelling reason to force a narrow, decontextualized reading of 'protection' onto the 1951 Convention. Giving the term 'protection' its ordinary meaning is consistent with the UNHCR's traditional view that the terms of the 1951 Convention and 1967 Protocol should be interpreted consistently with

individual human rights are violated, people are forced to flee to another country. Since community, refugees are protected by their governments, the international community steps in to ensure the individual's rights and physical safety.

'The 1951 Convention: Lasting Cornerstone of Refugee Protection', accessed in Aug. 2001 at In another section is

What sets refugees apart from other people who may be in need of humanitarian aid is their need for international protection. Most people can look to their own government and state institutions to protect their rights and physical security, even if imperfectly. Refugees cannot. In many cases, they are fleeing in terror from abuses perpetrated by the state. In other instances, they are escaping from oppression that the state is powerless to prevent, because it has lost control of territory or otherwise ceased to function in an effective way. By definition, refugees cannot benefit from the protection
of their own government. 'Issues: Asylum and Protection' accessed in Aug. 2001 at http://www.unhcr.ch/issues/ asylum/asylum.htm. 75 See e.g. Canada (Attorney-General) v. Ward, above n. 5, p. 711, in which UNHCR intervened to argue
that:

the distinction between 'unable' and 'unwilling' is irrelevant to this appeal, that there is no requirement for state complicity in the definition, and that the proper focus should be on whether the claimant, because of the state's inability to protect, is 'unable' or 'unwilling' to seek the protection of the authorities in his or her home state. The High Commissioner also endorses the position of the Board that the absence of protection may create a sufficient evidentiary basis for a presumption of a well-founded fear by the claimant.

Emphasis in original.

76 UNHCR, 'Note on International Protection Submitted by the High Commissioner', Executive Committee of the High Commissioner's Programme, 45th Session, UN doc. A/AC.96/830, 7 Sept. 1994, at para. 8. See also, paras. 1, 10, 11, and 22. 'the generous spirit in which they were conceived', so as to have an inclusive rather than restrictive meaning. ${ }^{77}$

\section{The logic of a shift to 'internal protection alternative'}

To this point we have established that, as a matter of principle, an understanding of refugee law as surrogate protection compels the view that if national protection can be delivered in some, but not all, parts of the State of origin, then refugee law should be applied in a way that recognizes the extant realities and possibilities for individuals and groups to benefit from the protection of their own country. While the existence of an internal alternative to asylum has sometimes been argued to defeat the existence of a well-founded fear of being persecuted, we have shown the dangers of such an approach - in particular, the tendency of States taking this view to impose a nearly impossible affirmative duty on asylum applicants to demonstrate a country-wide risk of being persecuted, and the implied legitimation of using the IFA inquiry to short-circuit a careful consideration of the affirmative elements of the refugee claim. In contrast, for the reasons set out in Section III, it is both more logical and linguistically satisfactory to view IFA analysis as relevant to the question whether national protection is available to counter the well-founded fear shown to exist in the applicant's region of origin.

The question remains, however, why we view it as important not only to clarify the appropriate textual home for the analysis of internal options to asylum, but also to propose a decisive shift in nomenclature and substantive focus - discarding the 'internal flight alternative' and 'internal relocation alternative' labels in favour of the notion of an 'internal protection alternative' (IPA), and rejecting the current UNHCR recommendation to analyze whether it is 'reasonable' to require the claimant to avail himself or herself of 'safety' in the proposed internal destination in favour of a commitment to assess the sufficiency of the protection which is accessible to the asylum seeker there. We set out our thinking on these points in this Part.

First, the use of the phrase 'internal flight' connotes a misconceived conceptual framework, suggesting as it does that the inquiry is to some extent retrospective. ${ }^{78}$

77 UNHCR, ‘Report of the United Nations High Commissioner for Refugees', UN doc. E/1995/52, 25 April 1995, p. 9 .

78 According to H. Storey, above n. 29, p. 3: 'Some leading cases still cited ... treat the IFA/IPA test as one of past flight. It would be useful to put paid to this misconception once and for all... [The] [c]entral focus must ... be on the question of whether upon return a person would be able to relocate to another part of the country of nationality.' But see R. Marx, 'Comments on James C. Hathaway and Michelle Foster, Internal Protection/Relocation/Flight as an Aspect of Refugee Status Determination', 31 Aug. 2001 (on file with authors). Marx argues that the phrase 'internal flight alternative' is to be preferred precisely because it restricts application of the principle to 
As adverted to in Section III, there is no justification in the Convention text for an implied exclusion or punitive provision based upon a failure to explore internal options before seeking asylum. ${ }^{79}$ Moreover, such an approach is inconsistent with the well-accepted notion that refugee analysis is concerned with future risk of persecution, and thus with assessment of risk at the date of determination. ${ }^{80}$ Although the current UNHCR formulation and most State practice now assume a prospective analysis, the continued use of the phrase 'internal flight' is dangerous. ${ }^{81}$ For example, some States have used the notion as an aspect of findings on credibility, arguing that, as the refugee claimant did not 'flee' internally, his or her claim for asylum abroad is not genuine. ${ }^{82}$ Phrasing the question as whether a person can 'relocate' within his or her country of nationality, while constituting a significant improvement on the notion of 'internal flight,' also conceptualizes the inquiry in an incorrect manner. The legally relevant issue is not the ability of the refugee applicant physically to move, but rather the degree of protection she or he will receive upon

which have arisen subsequent to that time, he argues, are relevant to the denial of refugee status concern raised by the cessation criteria of Art. $1 \mathrm{C}(5)$ of the 1951 Convention to be met. A key concern raised by this approach is the risk that refugee status could be denied to persons who had a protection option at the time of arrival, but who by the time of status determination may no longer have such an option. And while Marx is clearly correct that the declaratory nature of refugee status argues against allowing governments to invoke IPA the declaratory nature of during delays in processing refugee claims, in practice couts have rests which have emerged 1C(5) criteria to even long-delayed initial status assessments have resisted application of Art. (Minister of Employment and Immigration). Court of Canada observed that Art 1C(5) Trial Division, [1994] 3 FC 79 at 94, Reed J of the Federal

the revoking of status after it has been granted and with respect to which ... the of the initial determination as to whal has the burden of proof. In my view, in the context of the initial determination as to whether or not status will be granted, the question is a necessary to justify the revoking of status. The changed country conditions are necessary to justify the revoling of status. The question is whether the particular changed circumstances are relevant to the applicant's claim and how they relate
thereto.

79 See text above at nn. 11-12.

80 See e.g., Minister for Immigration and Multicultural Affairs v.Jama, Full Court of the Federal Court of Australia, [1999] FCA 1680, 3 Dec. 1999, at para. 24:

[T]he objective facts to be considered in reaching a determination as to whether the applicant's fear is well-founded are not confined to those which induced the fear. A current circumstances... There may be happen in the future, including any change in in circumstances may ... There may be no current risk of persecution ... yet a change in circumstances may teadily be foreseen that would create a significant risk of
persecution.

81 Despite emphasizing the prospective nature of the analysis, UNHCR continues to refer to the principle as an 'alternative to flight': see UNHCR, '1999 Position Paper', above n. 22, at para 11.

$82 \mathrm{ECRE}$, 'Position on the Interpretation of Article 1 of the Refugee Convention', 22 , at para. 11. versely, Portuguese and Spanish authorities consider that the fact thation', Sept. 2000. Confind a safe area before leaving the country of origin can be foundedness of the asylum claim: ELENA Research Paper, considered an indication of the well- arrival in the alternative site. $^{83}$ As neatly summarized by the New Zealand Refugee Status Appeal Authority:

[T] o pose any question postulated on 'internal flight alternative' is to ask the wrong question. Rather, the question is one of protection and is to be approached fairly and squarely in terms of the refugee definition, namely whether the applicant ' ... is unable or, owing to such fear, is unwilling to avail himself of the protection of that country' ${ }^{84}$

Secondly, since the focus is on protection, a term found in the Convention text and an inherent part of the analysis of a claim to refugee status, additional terms such as 'safety' and 'reasonableness' should not be made part of the test. These terms are vague and open to vastly divergent subjective interpretation. Most importantly, reliance on the notion of 'safety' has produced highly questionable results in particular cases, as it has been interpreted as meaning considerably less than 'protection'. For example, the Netherlands Rechtseenheidskamer takes the view that northern Iraq constitutes an IFA ${ }^{85}$ even though UNHCR advises that the Kurdish enclave in northern Iraq is 'volatile and may change at any time', the territory remains a part of Iraq, and NATO generals have conceded that they are not equipped to prevent Saddam Hussein's entry into the zone. ${ }^{86}$ Yet an analysis that asks only whether an internal site is 'safe' is open to such a finding, since the question of present and immediate safety may be construed to present a very low threshold. By contrast, a protection inquiry is forward-looking and, as will become evident below, is concerned with the durability of affirmative protection, rather than simply the immediate (and possibly short-term) ability to avoid persecution. ${ }^{87}$

The other key problem with the focus on the ability of an asylum seeker to find 'safety' in the country of origin is that it may be understood to impose an effective

83 According to Linden J of the Federal Court of Canada, 'A Brief Reaction to Hathaway's Paper', Sept. 2001 (on file with the authors): 'The advice to change the label of principles in this area to Internal Protection Alternative is particularly helpful, for it will focus our attention on the true issue that is involved here - whether protection can be obtained elsewhere in the country'; and L. D. Rosenberg of the US Board of Immigration Appeals, 'Commentary on Internal try'; and L. D. Rosenberg of the US Board of Immigration Appeals, 'C
Flight/Protection Alternative', Sept. 2001 (on file with the authors):

It is desirable to use 'internal protection' because that language emphasizes the fact that it is protection that is at the center of the inquiry as to whether there should be surrogate protection afforded by the receiving state. It is in determining whether internal protection is available that we can conclude whether a refugee is in need, now, of protection.

84 ReR.S., New Zealand RSAA, Decision No. 135/92, 18 June 1993.

85 See ELENA Research Paper, above n. 3, pp. 40-1.

86 UNHCR, 'Action Plan on the Influx of Iraqi Asylum-Seekers: UNHCR Observations', memo to the K4 Committee of the Council of the European Union, Brussels, 21 April 1998, as cited in Frelick, above n. 6, p. 26. See generally, Frelick, above n. 6, pp. 24-7.

87 See text below at n. 120, and at nn. 157-85. 
duty on the applicant to hide or 'go underground' in order to avoid detection. ${ }^{88}$ In other words, UNHCR's rather fungible safety standard can be interpreted as asking, 'Is it somehow possible for the asylum seeker to avoid domestic harm?' rather than "Can the individual secure access to domestic protection?" ${ }^{89}$ This approach is evident in cases that view as decisive the fact that an asylum seeker has somehow managed to avoid persecution for a short period before fleeing his or her home State. For example, in R. v. Immigration Appeal Tribunal, ex parte Guang, the applicant had incurred a fine for breaching the one-child policy in China and had subsequently displayed a poster in his village expressing the view that the government imposed lighter penalties on well-connected people. A warrant was issued for his arrest and he fled to Shanghai where he stayed with a friend for two months before escaping to the United Kingdom. A UK court rejected his claim for asylum on the basis that he did not suffer persecution during the two months he hid in Shanghai. ${ }^{90}$

More generally, an emphasis on 'safety' alone runs a significant risk of encouraging a view that it is incumbent upon the asylum seeker to avoid persecution in the proposed internal destination by suppressing his or her political or religious beliefs in order to avoid detection by the relevant authorities. There are a number of worrying examples of courts apparently taking such an approach by reference to the safety standard, particularly in cases involving opponents of the one-child policy in China. ${ }^{91}$ In one decision of the Australian Federal Court involving a medical practitioner who was involved in political activity directed at opposition to the one-child policy, including frequently writing angry letters to government officials objecting

88 For example, in Ahmed v. Canada (Minister of Employment and Immigration), [1993] FCJ 718, the Canadian Federal Court of Appeal considered the claim of a Imigration), [1993] FCJ 718, the League who had been able to avoid harm in his country for fourteen mi member of the Awam tual hiding with a family in a distant town, working as their private months by going into vir the home. As the Court concluded: 'The mere fact that as their private cook, and rarely leaving out significant problems in Chittagong, away from that the appellant lived a certain time withsufficient to conclude that he could rely on from his home and half in hiding, is obviously not 89 Indeed, UNHCR's 1999 ela could rely on state protection in his country.'

is 'whether the risk of persecution that an individual experiences in one part the relevant question successfully a voided by living in another part of the country': ก. 22, at para. 9 (emphasis added).

90 R. v. IAT, exparte Guang, English High Court (QBD), Decision No. CO/3029/98, 1 Sept. 1999.

91 E.g., in R. v. IAT, exparte Sui Rong Suen, (1997] Imm,, Decision No. CO/3029/98, 1 Sept. 1999. the rejection (by the tribunal below) of the claim of a 16-year-old Ching Court (QBD) upheld UK after throwing a rock at police who were brutalizing hear-old Chinese girl who fled to the policy. She first went to her grandmother's brutalizing her mother for violating the one-child were looking for her to her grandmother's home, but stayed only a few days because the police were looking for her there. She then went to a friend's place one-and-a-half hours away from her village. After a week, her father advised her to leave the country, and bribed an official to obtain passport for her. The IAT, with very little analysis, found internal flight to be viable because there was no evidence that authorities had pursued her outside her province. The viable because there affirmed the decision since, '[o]n the findings of fact of the adjudicator it is be no persecution, in his view, in any part of China other than the Fujis clear that there would This decision implies that the fact that she of China other than the Fujian Province' (at p. 363). the recognition of refugee status. to the one-child policy, the Court found an internal flight alternative to exist since there was evidence that 'the applicant had, in fact, been able to restrain herself from expressing her opinions on the question of the one-child policy between 1992 and $1996{ }^{.92}$

This 'duty of restraint' is inconsistent with the very premise of the 1951 Convention, that is, that individuals have a right to be free of persecution for reasons of their political beliefs (and other grounds), which presupposes a freedom to express and act upon those political beliefs. It can never be acceptable for decision makers to require asylum seekers to avoid persecution by denying their fundamental civil and political rights such as freedom of expression of opinion and of association and freedom to express and practise religious beliefs. ${ }^{93}$ Given the Preamble's affirmation that the refugee regime is premised on 'the principle that human beings shall enjoy fundamental rights and freedoms without discrimination', refugee status may not be refused simply because an applicant could live in safety by declining to exercise his or her fundamental beliefs. As the Full Court of the Federal Court of Australia has recognized in a different case:

[A]n assumption that a person with a strongly held religious belief should act reasonably, and compromise that belief to avoid persecution, would be contrary to the humanitarian objects of the Convention. ${ }^{94}$

An approach which looks not merely to 'safety', but instead to the sufficiency of (affirmative) protection, ensures that such concerns do not arise.

Beyond its insistence on an analysis of protection rather than safety, the IPA standard also differs from UNHCR's traditional formulation by the fact that the duty to seek internal protection is not predicated on an assessment of whether or not it would be 'reasonable' for the asylum seeker to accept internal protection. While superficially liberal, the 'reasonableness' test in practice allows decision makers to assess the asylum seeker's alternatives in light of their own view of what constitutes 'reasonable' behaviour. As Frelick rightly observes:

92 Ye Hong v. Minister for Immigration and Multicultural Affairs, [1998] FCA 1356, 2 Oct. 1998.

93 Indeed, it is recognized that persons at risk because they are members of 'groups whose members voluntarily associate for reasons so fundamental to their human dignity that they should not be forced to forsake the association' are entitled to refugee status on grounds of membership of a particular social group: Ward, above n. 5, p. 739. The importance of not requiring applicants to abdicate their religious beliefs in order to remain inside their country was recognized, for example, in a German case concerning Turkish citizens of the Yezidi religion. The Federal Consticution tutional Court held that the was no religious persecution. By continuing to practise their religion they would be faced with severe financial hardship and they could not be expected to compromise their religious beliefs in order to avail themselves of safety. See ELENA Research Paper, above n. 3, p. 34.

94 Wang v. Minister for Immigration and Multicultural Affairs, [2000] FCA 1599, at para. 85, where Merkel J paraphrases and adopts the previous decision of the Full Court of the Federal Court of Australia in Omar v. Minister for Immigration and Multicultural Affairs, [2000] FCA 1430 at para. 42. Merkel J helpfully summarizes the authority for this proposition: see generally paras. 82-91. 
Reasonableness, as Alice no doubt would observe, depends on which side of the looking glass one is standing. Viewed from the host country perspective, the risks and dangers to asylum seekers back in their far away countries may appear less threatening than they do from the perspective of persons who have directly experienced those conditions up close and who fear being sent back through the looking glass to experience them again. ${ }^{95}$

Even UNHCR's 1999 position paper suggests only an open-ended list of possible menu items that States may choose to consider in assessing reasonableness. ${ }^{96}$ Decision makers are thus required to make their own individual assessments as to what is 'reasonable' in a particular case. Such an amorphous test is not amenable to structure or guidance by appellate courts. Storey has remarked on the situation in the United Kingdom that, 'despite seeing the IFA as an essential element of the 1951 Convention scheme, there has been little sign that UK judges have either welcomed or seen the necessity for decision makers either to analyse it or apply it themselves within a clear or settled framework of analysis'. ${ }^{97}$

This inherent lack of analytical clarity produces wide inconsistency between jurisdictions. For example, while decisions in Denmark, the Netherlands, and the United Kingdom have generally held that the presence of family in the proposed internal destination is not necessary, other decisions, particularly in jurisdictions such as Canada, Finland, Switzerland, and New Zealand, have insisted on the relevance of family and other social networks. A similar divergence is evident in respect of other factors comprising the 'reasonableness' test. For example, the Netherlands Council of State has held that the prospect of the deterioration of an asylum seeker's socio-economic status will not prevent an IFA from being recognized, ${ }^{98}$ the Danish Refugee Appeals Board is unlikely to take account of socio-economic factors in deciding whether an internal option is reasonable, ${ }^{99}$ and the Canadian Federal Court has denied the relevance of the potential for economic prosperity in assessing the viability of an IFA. ${ }^{100}$ On the other hand, German ${ }^{101}$ and Swiss ${ }^{102}$ courts have

95 Frelick, above n. 6, p. 23

96 It is said that the claimant's personal profile will be important and that factors to be considered might include but are not limited to age, sex, health, family situation and relationships, ethnic and cultural group, political and social links and compatibility, social or other vulnerabilities, language abilities, educational, professional, and work background, and any past persecution suffered and its psychological effects: UNHCR, '1999 Position Paper', above past petsecution

97 H. Storey, 'United Kingdom Case Law on "Interal Plight Alterner', above n. 22, at para. 16. Nationality Law and Practice, 1997, p. 57 at p. 58. 98 Decision No. A-2.0273, 1997, p. 57 at p. 58

99 See ELENA Reserch Paper, above Council of State, 1980.

99 See ELENA Research Paper, above n. 3, p. 30.

Singh v. Canada (Minister of Employment and Immigration), Federal Court of Canada(Trial Division), [1993] FCJ 630, 23 June 1993.

101 See e.g., the decision of the Bavarian Administrative Court, AN 12 K 89.39598, 30 May 1990, and the decision of the Bavarian Higher Administrative Court, Az. 24 BZ 87.30943, 15 Nov. 1991.

102 In a decision of the Swiss Asylum Appeal Board (French-speaking division), 6 Dec. 1994, 2nd Ch., No. 175 287, it was held that there was no IPA for the Yezidis in the entire Turkish territory sometimes argued for the relevance of economic or financial hardship in assessing the adequacy of an IFA. A similar divergence can be seen in relation to language skills. While decision makers in New Zealand have held that an absence of relevant language skills does not rule out internal relocation, courts in Switzerland and Canada have held that the ability to speak the language of the relocation alternative is highly relevant. We agree with de Moffarts' conclusion that ' $[t]$ he reasonableness approach tends to an eclectic or ad hoc jurisprudence concerning claimants from the same countries and in similar situations'. ${ }^{103}$

Indeed, application of the 'reasonableness' standard may even produce inconsistent results within the same jurisdiction. This is exemplified in a series of cases before the Canadian Federal Court involving consideration of the possibility of relocation to Colombo by older Sri Lankan Tamils. On the one hand, the Court considered internal relocation a reasonable alternative for an 82-year-old Tamil, confined to a wheelchair, impoverished and isolated from family. ${ }^{104}$ On the other, the Court rejected the possibility of requiring relocation to Colombo for a 75 -yearold Tamil woman who had no family there, ${ }^{105}$ and remanded another case because the tribunal panel had failed to consider that the applicant was a widow in her sixties with no family support or connections in Colombo and with no knowledge of English or Sinhalese. ${ }^{106}$ This analysis makes plain that the 'reasonableness' of an IFA is essentially in the eye of the beholder.

Not only is the reasonableness standard prone to arbitrariness, but it involves an unfocused and open-ended inquiry which is not anchored in the language or object of the 1951 Convention. Many of the factors frequently taken into account by decision makers in this context have more relevance to immigration law-based humanitarian applications than to determinations under the Convention definition. For example, where applicants have a low level of education, do not speak the dominant language of the proposed destination, and have limited employment experience, decision makers are more likely to reject a submission that an internal relocation alternative is available to the applicant. As an Australian tribunal held:

The applicant has lived in the Jaffna area all his life. He has never lived or worked in Colombo (with the exception of four months before his departure to Australia). He does not speak Sinhalese and has never had a job. He has limited education. As an inarticulate, elderly person from the north who

where, following the emigration of a large part of their population, they no longer had a socioeconomic network.

103 De Moffarts, above n. 30.

104 Periyathamby v. Canada (Minister of Citizenship and Immigration), Canadian Federal Court (Trial Division), (1995) 26 Imm LR (2d) 179.

105 Ramanathan $v$ Canada (Minister of Citizenship and Immigration), Canadian Federal Court (Trial Division), Decision No. IMM-5091-97 (1998); 1998 Fed. Ct. Trial Lexis 1017.

106 Jayabalasingham v. Canada (Minister of Citizenship and Immigration), Canadian Federal Court (Trial Division), Decision No. IMM-140-98 (1998); 1998 Fed. Ct. Trial Lexis 1283. 
speaks no Sinhalese, the applicant would be particularly vulnerable ... I am satisfied that it would not be reasonable to require him to relocate to Colombo where there are continuing large-scale round-ups of Tamils, arbitrary detention of Tamils, and continuing human rights abuses on the part of the [Sri Lankan security forces]. ${ }^{107}$

The difficulty with such cases is that decision makers do not explain why educated, employable people are less at risk of suffering from 'continuing large-scale round-ups of Tamils, arbitrary detention of Tamils, and continuing human rights abuses' than uneducated claimants. These cases tend to conflate the considerations relevant to refugee status with those more relevant to an application for entry on humanitarian or compassionate grounds. Indeed, the humanitarian nature of the inquiry has been explicitly acknowledged by some adjudicators. ${ }^{108}$ Yet it is difficult to understand why an extra-legal discretion, by application of the humanitarianbased reasonableness test, should reside in decision makers in respect of only this aspect of the 1951 Convention. If it is justified in this context, then one might wonder why it is not equally justified in respect of other aspects of the definition. For example, where serious harm in respect of which a person is at risk does not amount to 'persecution', why should decision makers not consider whether it is nonetheless unreasonable to expect the applicant to endure it on return to his or her home country?

This objection is not merely a theoretical one; rather, it is this very lack of justification for the reasonableness test in the Convention text that makes it an unwieldy basis upon which to anchor the assessment of an internal alternative to asylum. This point is well exemplified in the judgment of the New Zealand Court of Appeal in Butler v. Attorney-General:

[T] he various references to and tests for 'reasonableness' or 'undue harshness'... must be seen in context or, to borrow [the English Court of Appeal's] metaphor, 'against the backcloth that the issue is whether the claimant is entitled to the status of refugee'. It is not a stand alone test, authorising an unconfined inquiry into all the social, economic and political circumstances of the application including the circumstances of members of the family...

Rather than being seen as free standing... the reasonableness test must be related to the primary obligation of the country of nationality to protect the claimant... The reasonableness element must be tied back to the definition

107 Decision No. V96/05239, Australian RRT, 11 March 1997.

108 For example, in Jayabalasingham, above n. 106, Richard J held that, when the tribunal had stated that the reasonableness of the IPA requires 'some additional or extraordinary hardship', it had erred by bringing the threshold of the test beyond humanitarian and compassionate considerations. See also Ramanathan, above $n .105$, in which Hugessen I held that it is incore considerclude humanitarian and compassionate grounds when considerig the posibitity of clude humanitarian and compassionate grounds when considering the possibility of internal
protection. of 'refugee' set out in the Convention and to the Convention's purposes of original protection or surrogate protection for the avoidance of persecution. ${ }^{109}$

The risk of continuing to insist on this approach therefore is that any careful interpreter of the 1951 Convention will eventually be drawn to the position articulated by the UK Immigration Appeals Tribunal in Ashokanathan that 'reasonableness' is simply a kind of 'humanitarian gloss' on strictly legal treaty obligations. ${ }^{110}$ Indeed, Canadian courts now set 'a very high threshold for the unreasonableness test'. ${ }^{111}$ By contrast, an analysis focused on the sufficiency of protection has the distinct advantage of being a standard actually derived from a treaty that States have formally agreed to be binding on them. In addition, it provides a focused and principled framework of analysis, based on the aims and objects of the 1951 Convention.

\section{Steps for assessment of an internal protection alternative}

In order to determine whether a claim to refugee status may lawfully be denied on grounds of an internal protection alternative (IPA), four criteria must be considered. First, is the proposed IPA accessible to the individual - meaning access that is practical, safe, and legal? Secondly, does the IPA offer an 'antidote' to the wellfounded fear of being persecuted shown to exist in the applicant's place of origin that is, does it present less than a 'real chance' or 'serious possibility' of the original risk? Thirdly, is it clear that there are no new risks of being persecuted in the IPA, or of direct or indirect refoulement back to the place of origin? And, fourthly, is at least the minimum standard of affirmative State protection available in the proposed IPA?

In this section, we outline the considerations relevant to the application of each of these four analytical steps. As we hope to make clear, far from being a radical departure from prior practice, the IPA approach merely draws together the 'best

109 Butler v. Attorney-General, above n. 71, p. 218.

110 Ashokanathan, Decision No. 13294, UK IAT. According to C. Yeo, "The "Internal Flight Alternative": Counter-Arguments', 15(1) Immigration, Asylum and Nationality Law, 2001, p. 9 at p. 16:

Looking to the future, the approach to an internal protection alternative advocated in the Michigan Guidelines on IPA and adopted in New Zealand seems preferable to the current $U K$ position. Uncertainty would also be reduced and the approach is more readily compatible with the text of the Convention. It might also lead to a higher success rate in asylum applications. While the Michigan approach may appear to restrict positive discretion, Adjudicators might prove to be more amenable to accepting IFA positive discretion, Adjudicators might prove to be more amenable to accepting IFA
counter-arguments if such arguments were more firmly based on a logical foundation.

111 Canada (Minister of Citizenship and Immigration) v. Ranganathan, Canadian Federal Court of Appeal, Decision No. A-348-99, 21 Dec. 2000 
practice' of State Parties in a legal framework directly derived from the 1951 Convention itself. For this reason, the IPA approach is neither inherently more liberal nor more conservative than earlier formulations; it is simpl a framework explic State.

\section{A. Step 1: accessibility}

Since IPA analysis is concerned with the possibility of a present source of alternative internal protection, the first question is whether the asylum seeker can in fact gain access to the region proposed as an IPA. This notion that the IPA must not be 'merely theoretical or abstract'112 is already a well-accepted proposition in the jurisprudence of States Parties: ${ }^{113}$

[N]otwithstanding that real protection from persecution may be available elsewhere within the country of nationality ... [IPA does not apply] if, as a practical matter, the part of the country in which protection is available is not reasonably accessible to that person. In the context of refugee law, the practical realities facing a person who claims to be a refugee must be carefully
considered. ${ }^{114}$

Closely related to the question of practical accessibility is the duty to assess the physical risks entailed in the process of travel to or entry into the IPA. This has also been well recognized in State practice. ${ }^{115}$ For example, in Dirshe v. Canada (Minister of Citizenship and Immigration), the Canadian Federal Court emphasized this concern in a case where travel to the proposed IPA involved passage through an area in which violent gangs and roving militia were present:

112 Decision No. N94/03786, Australian RRT, 1995.

113 For example, the US Court of Appeals for the Third Circuit held in Etugh, above n. 14, that there was an IPA for the Nigerian claimant because the deportation procedur, aboven. out the applicant having to re-enter his hometown (where a clear riss existed). Applyinth converse proposition, the UK IAT in Baglan (Decision Kurd on the grounds that the Home Office proposed to deport granted the appeal of a Turkish enclave', but rather to Istanbul (where he was found to deport him not to the identified 'safe J stated in Thirungru Istanbul (where he was found to face the risk of persecution). As Linden $J$ stated in Thirunavukkarasu v. Canada, above n. 25, p. 598, '[a]n IFA cannot be speculative or theoretical only; it must be a realistic, attainable option'.

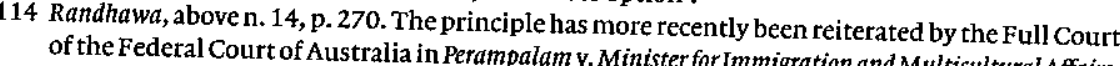
(1999) 84 FCR 274, at 288 per Moore J.

115 The US BIA held in Matter of H. (BIA, Decision No. 3276, 1996) that it would be prepared to give claimant only if first provided with clan that an internal protected area existed for the Somal daimant only if first provided with clarification of just how the government would propose to deport the individual to the protected area (in view of the dangers between Mogadishu- where access was possible - and the allegedly safe area).
The Tribunal erred in law in its assessment of the applicant's fear of gangs and roving militia in relation to the [IPA]. In order for an [IPA] to be viable, it must be physically possible for the applicant to get there. This involves an assessment of how the applicant is to get there. If it is dangerous for the applicant to get to the safe area, it cannot be said that the [IPA] is a practical possibility. ${ }^{116}$

The final aspect - legal accessibility - has two dimensions. First, it is imperative that an asylum seeker not be returned to an IPA where return requires passage through an intermediate State which will not legally permit the asylum seeker's entry. For example, a Kurd could not be returned to northern Iraq via Turkey if Turkey will not grant a visa to permit entry into Turkey. This was emphasized by the Federal Court of Australia in Al-Amidiv. Minister for Immigration and Multicultural Affairs:

The Tribunal was satisfied that the applicant could not enter Iran or Syria and was likely to be satisfied on the evidence before it that he could not enter Turkey. There was nothing before the Tribunal to allow it to be satisfied that the applicant would be given travel documents, and, if returned from Australia, that he would be able to enter northern Iraq. Indeed, the Tribunal did not consider that question. That represented a fundamental flaw in the decision-making process and one which meant that the task set for the Tribunal by the Act was not carried out. ${ }^{117}$

Secondly, since the rationale of internal alternative protection is that refugee status is not required to be granted where the applicant's own government is able to protect him or her in at least part of the country of origin, it would make little sense to deny asylum on the basis of an internal option that the national government has formally made unavailable to the applicant. ${ }^{118}$ As was well explained by the Canadian Federal Court in Sathananthan v. Canada, in refusing to recognize the existence of an IPA for a Tamil in Sri Lanka:

[T]he applicant's evidence was that he was ordered by the police in Colombo to go North within 48 hours - a place where ... the applicant had a

116 Dirshe v. Canada (Minister of Citizenship and Immigration), Federal Court of Canada(Trial Division), Decision No. IMM-2124-96 (1997), 1997 Fed. Ct. Trial Lexis 521.

117 Al-Amidi v. Minister for Immigration and Multicultural Affairs, above n. 71, pp. 510-11. See also, the decision of the Bavarian Higher Administrative Court, which held that a Kurdish asylum seeker could not be expected to return to northern Iraq as he did not possess any valid travel documents, without which he would be unable to access the territory of northern Iraq via Syria, Turkey, or Iran and there would be no other legal way of entering northern Iraq, Decision No. 23 B 99.32990, 23 March 2000, cited in ELENA Research Paper, above n. 3, p. 35.

118 For example, the UK IAT correctly held in Yang (Decision No. 13952, 1996) that no relocation alternative existed for the Chinese applicant in that case, since " $\mathrm{oln}$ the background evidence available to us it seems that China administratively controls where its citizens may live and there is therefore no freedom of internal movement without consent? 
well-founded fear of persecution ... [The] finding [of internal protection] is grounded in faulty analysis... based... [inter alia] on a contradiction (one can stay in Colombo but if one does one will be breaking the law and will be arrested). ${ }^{119}$

Once practical, safe, and legal accessibility to the proposed IPA has been established, the inquiry turns to an assessment of the quality of protection available in the IPA. This in turn involves a threefold analysis: does the IPA constitute an 'antidote' to the original risk of being persecuted; are there new risks of being petsecuted, or of refoulement to the region of origin; and is the level of affirmative protection available in the IPA consistent with the minimum acceptable standard?

\section{B. Step 2: antidote}

An IPA can obviously be said to exist only in a place where the applicant does not face a well founded fear of being persecuted. It is not, however, sufficient simply to find that the original agent of persecution has not yet established a presence in the proposed site of internal protection. Rather, there must be reason to believe that the reach of the agent of persecution is likely to remain localized outside the designated place of internal protection. For example, a German court found that a Lebanese asylum seeker could not avail himself of an IPA as Syrian troops, who perceived the applicant to be an opponent of the Baath party in power in Syria, were in the process of expanding their already extensive control over a large part of Lebanon. The Court thus held that 'it was... not certain that the applicant would be safe from persecution by the Syrian military fertain that the applicant time?.120

The method of measuring the degree of risk in the IPA is the usual 'well-founded fear' test, that is, whether there is a 'reasonable possibility', 'reasonable chance', or 'real chance' of being persecuted in the IPA. On the one hand, a fear of being persecuted is well founded even if there is not a clear probability that the individual will be persecuted. On the other hand, the mere chance or remote possibility of being persecuted is an insufficient basis for the recognition of refugee status. The relevant inquiry is whether there is a significant risk that the individual may be persecuted in the IPA in the foreseeable future.

Clearly, an inquiry into the potential for an IPA to provide an antidote to the persecution feared in the localized region presupposes an initial assessment of the nature and degree of the well-founded fear in the applicant's region of origin. This is because the antidote required will vary considerably according to the risk of persecution faced in the first region. Thus, protection that is meaningful and effective in one case may not be so in another. For example, while a man who fears guerrillas requires protection from a strong government military that can confine the threat to localized regions, a strong military that can suppress guerrilla activity may be meaningless for a woman fleeing domestic violence who needs assertive police protection. This again serves to highlight the importance of approaching the inquiry in a methodical manner, beginning with an assessment of well-founded fear before proceeding to the protection assessment. An analysis that conceives of IPA as part of the initial well-founded fear assessment obscures the importance of this two-stage assessment and runs the risk of producing an inadequate assessment of continuing risk in the intended IPA.

In practical terms, a decision regarding the existence of an IPA is a function of (a) the ability of the agent of persecution to be present in the IPA; ${ }^{121}$ and (b) the likelihood of pursuit in the IPA. A Canadian decision illustrates the interplay of these two essential elements in the inquiry:

[In rejecting the claimant's application, the Immigration and Refugee Board] failed to address the applicant's evidence that the applicant's husband is a sophisticated, vindictive and obsessed individual and that, based on his past conduct, he would be able to track down the applicant anywhere in Peru, even without his political connections [to the Shining Path].

Inter alia, the Board suggested that a reasonable [IPA] existed outside Lima, as the applicant could find employment as a teacher. However, it did not deal with the submission that the applicant's husband could trace her through the Ministry of Education. Further, despite finding state protection had been refused in the past, the Board offered no substantive reason to justify that the applicant would be safe outside Lima. ${ }^{122}$

In this decision, the Court appropriately considered the fact that the husband was sophisticated and well connected in the government and the Shining Path (that is, capable of pursuit) and that he was obsessed (that is, likely to pursue).

The frequent concern of courts with whether the asylum seeker is a prominent activist or relatively anonymous should similarly be understood to inform the issue

121 E.g., the Federal Court of Canada found that an Argentinian claimant opposed to mandatory union dues and a member of the Radical Civic Union party (UCR), faced the risk of beatings by trade unionists. But the court found a valid IPA because 'there are municipal and provincial jurisdictions controlled by political opponents of the Justicialista (Peronist) Party and its trade union allies ... [T] he claimant could live safely in provinces of Argentina controlled by the UCR': Vidal v. Canada (Minister of Employment and Immigration), Fed Argentina controlled by Division), Decision No. A-644-92 (1997); RSAA, Decision No. 1613/93, the tribumal found that a low caste Sind RSAA, Decision No. 1613/93, the tribunal found that a low caste Indian could find internal protection 'by relocating either to Uttar Pradesh or Bihar [where] the appellant would be able to take advantage of the lower caste governments there in power.

122 Gonzales-Cambana v. Canada (Minister of Citizenship and Immigration), Federal Court of Canada (Trial Division), Decision No. IMM-933-96 (1997); 1997 Fed. Ct. Trial Lexis 689. 
of the likelihood of pursuit by the agent of persecution into the proposed IPA. ${ }^{123}$ However, as emphasized above, it is vital that adjudicators be careful to avoid transforming this analysis into a duty on behalf of claimants to become anonymous by suppressing their political or religious views or by hiding from the agents of persecution in the new site. ${ }^{124}$ As the Australian Refugee Review Tribunal held in a case rejecting the possibility of an IPA for a person at risk because of strong religious convictions, " $[t]$ he issue of internal flight is not a significant one when one takes the approach of considering the likely conduct of the applicant upon return, for one may expect that this conduct would be the same whatever part of the country he returned to. ${ }^{125}$

Perhaps the most important and controversial issue that arises under this element of the IPA analytical framework is whether there can ever be an effective antidote inside the applicant's country of origin where the agent of persecution is the government itself. In short, is the very idea of an IPA in the face of a risk of being directly persecuted by the government logically inconsistent, given that the 1951 Convention conceives of the national government as the source of legally relevant protection ('... unable or ... unwilling to avail himself of the protection of that country...')? Comparative jurisprudence reveals divergent answers to this
question.

At one extreme, some decision makers have taken the view that whether or not the persecutor is the State is completely irrelevant to the analysis. ${ }^{126}$ However, these

123 For example, the Administrative Court of Austria found that well-known Kurdish opposition figures in Iraq could not find protection in the 'safe' Kutdish zone bewn Kurdish opposition ties in the autonomous safety zone are not in a safe' Kutdish zone because 'Kurdish authoriof persecution by Iraqi authorities. The evidence presen to protect the applicant from danger believe that, absent concrete proof to the contrary, it cret police could undertake activities directed ag, it would not be improbable that the Iraqi sezone of Northern Iragtake activities directed against known opposition fighters in the safety zone of Northern Iraq, without effective hindrance from the Kurdish authorities. Therefore there is no [IPA] available for the applicant': Decision No. 95/20/0284, 12 authorities. Therefore translation).

124 See the text above at nn. 88-90. For example, in In Re C.A.L., above n. 33, the US BIA inappropriately relied on a lack of notoriety to reject a Guatemalan man's asylum claim on the basis of
an IPA, finding (inter alia) that '(w) of harassment by the respondent to be a high profile victim rassment by the guerrillas' (p. 5). This was significant given that:

[t]he Department of State country conditions report on Guatemala states that the numbers of guerrillas have declined through the years, the guerrillas are concentrated control, and the threat to the general population has deccessible to government Ibid., p. 5.

125 Decision No. V96/04931, Australian RRT, 25 Nov. 1996.

126 For example, in Matter of R., above n. 33, the US BIA held that:

[a]ssuming, arguendo, that he previously suffered persecution in Punjab, on the

sought refuge record before us, we do not find it unreasonable to expect him to have

sought refuge elsewhere in India. In view of the unrebutted opinion of the Department decisions tend to be problematic, as they often ignore the superior capacity of the State to pursue the applicant into alternative regions or impose an effective obligation on the applicant to hide from the State in an alternative location.

At the other extreme, some courts have taken the view that if the agent of persecution is the government an IPA can never exist. ${ }^{127}$ This approach has the advantage of ensuring that the benefit of any doubt regarding the government's potential for continued persecution in the alternative region is resolved in favour of the asylum seeker. In addition, it is consistent with the general position in international human rights law. ${ }^{128}$ However, it may also be too simplistic, as it fails to consider the different types of government entities and their varying capacity for nationwide persecution.

We recommend a middle ground approach which takes into account the differences between levels of government, as well as divergences in the degree of governmental implication in the risk of being persecuted. The most straightforward type of case, where the application of an IPA test is most obviously appropriate, is one in which the State is not the agent or sponsor of the persecution, but is simply unable to respond to the risk posed by non-State agents in a particular region. In such cases there is no reason to assume that the government cannot be trusted elsewhere in the country. Thus, these cases should be analyzed as standard IPA claims, without any particular presumption as to outcome. Decision makers should nonetheless carefully consider all relevant factors, including whether the State is truly willing but unable to provide protection in the applicant's home region, whether the persecuting group's activities (or the government's inability to control the group's activities) are truly limited to one region, and whether in the IPA the government effectively protects similarly situated persons.

On the other hand, the least logical situation in which to find an IPA is where the agent of persecution is the national government itself. Where, for example, harm is threatened by the police or military of a country, or where the national government

of State ... we find that a preponderance of the evidence establishes that conditions in India, outside Punjab, are not such that the applicant would have a well-founded fear of returning to that country.

127 In decisions involving Tamils from Sri Lanka and Kurds from Turkey, the Netherlands Council of State has refused even to consider internal relocation, holding in effect that internal relocation is excluded if the national authorities are the agent of persecution (A.R.R. v. S. (1982); R.V. (1982);A.R.R. v. S. (1988) and R.V. (1994)). The Swiss Asylum Appeal Board (French-speaking division), 21 April 1993, 4th Ch., No. 138356 , has held that there is no possibility of internal protection where the asylum seeker is directly persecuted by the central authorities. In that case the Board recognized the claim to asylum of a member of the Turkish Communist Party/MarxistLeninist who had been Iabelled an 'undesirable person' by the Turkish authorities.

128 For example, in Alan v. Switzerland, UN Doc. CAT/C/16/D/21/1995, 8 May 1996, the Committee Against Torture addressed the claim of a rejected Kurdish asylum seeker from Turkey. The Committee, concerned that the agent of persecution was the Turkish State itself, found that there was no safe area for the applicant inside Turkey. 
actively sponsors or supports the persecutory activities of a theoretically independent agent, there should be a strong presumption against finding an IPA. ${ }^{129}$ Indeed, the presumption against IPA in such circumstances may logically be defined as verging on irrefutable. ${ }^{130}$ This is consistent with the view of UNHCR that, "in the overwhelming majority of cases involving a fear of State agents of persecution, the availability of a safe internal alternative will not be a relevant consideration', ${ }^{131} \mathrm{~A}$ national government presumably has the capacity to pursue anywhere within its jurisdiction. When the State has itself threatened a person in his or her home region, even a small chance that the government will pursue the person logically amounts to a genuine risk of harm. ${ }^{132}$ As explained by the US Court of Appeals for the Ninth Circuit in Singh v. Moschorak:

All that is required for refugee status to be recognized is a 'real chance', a 'serious possibility' of persecution. Even if the national government presently sees no reason to persecute a particular group in a particular place, it has already demonstrated its willingness to persecute elsewhere. Surely this alone - unless there has been a fundamental change of government - is

129 Recently promulgated US regulations establish a presumption that internal relocation is not reasonable where the persecutor is a government or is government-sponsored, unless the INS 'establishes by a preponderance of the evidence that, under all reasonable for the applicant to relocate'(US Regulations, above n. 3).

thought that there are Court of Appeals for the Ninth Circuit observed that it has never been engaged in the acts of punishing opinion a nation when it is the nation's government that has v. Moschorak, $53 \mathrm{~F} 3 \mathrm{~d} 1031$ at 1034 (9th Circuit) 1995 ; Chanctim to leave the country': Singh 5066 (9th Circuit), 27 March 2000.

132 This approach has also Paper', above n. 22, pp. 1-3. Art. 3 of the 1950 European Convention for the Protection of Human Rights and interpreting Freedoms, ETS No. 5. In Chahal v. United Kingdom (Decision No. 70/1995/576/662, 1996), Court was concerned with an application for asylum in the No. 70/1995/576/662, 1996), the persecution in the Punjab region of India. The UK offered to send himh separatist, who alleged claiming that only the local Punjabi police posed a real risk, send him to another part of India, in any event. Chahal introduced evidence that Sikh separatich had lessened in recent years rest, extrajudicial execution, and torture that Sikh separatists are at risk of disappeatance, arChahal's evidence execution, and torture anywhere in India. The Court essentially accepted ahal's evidence and rejected the possibility of an IPA:

most at risk from the of the opinion that Mr Chahal, if returned to India, would be most at risk from the Punjab security forces acting either within or outside State human tights violattions significance to the fact that attested allegations of serious human tights violations have been levelled at the police elsewhere in India.

Ibid., para. 104.

In a more recent decision, the European Court of Human Rights in Hilal v. United Kingdom Decision No. 45276/99, 6 March 2001, rejected the UK Government's Hilal v. United Kingdom, nal flight' option existed in mainland Tanzania for an applicant fleing persecution an 'interibar. The Court explained that " $t$ the police in mainland institutionally to the police in Zanzibar as part mainland Tanzania may be regarded as linked guard against arbitrary action' (at para. 67). enough to meet the 'real chance', 'serious possibility' standard throughout the country over which that government has authority. ${ }^{133}$

The logic of avoiding consideration of IPA when an official organ of the national State is the direct or indirect agent of persecution is well illustrated in the recent decision of the Federal Court of Australia in Minister for Immigration and Multicultural Affairs $\mathrm{v}$. Jang, a case in which internal protection was assessed in relation to a Christian woman fearing persecution on religious grounds in China as a result of the enforcement of a national law restricting religious practices. One of the issues to be considered by the Court was whether the tribunal below had erred in failing to consider the IPA option since the enforcement of the national law varied between regions. The Court rejected the notion that the possibility of internal protection was an appropriate consideration in such a case:

However, where the feared persecution arises out of action taken by government officials to enforce the law of the country of nationality, or to implement a policy adopted by the government of that country, it will be much more difficult for [a] ... decision maker to reach satisfaction that there is no real risk of the refugee applicant being persecuted if returned to that country. In such a case, if there is a safe area, this must be because the responsible officials have failed to discharge their duty to enforce the relevant law or policy... That situation might change overnight, either because of the appointment of one or more new officials or insistence on enforcement by superior offices. There will often (perhaps usually) be a 'real risk' of that happening. ${ }^{134}$

It should be emphasized that this extreme caution against considering IPA applies both in cases where the national government is the direct persecutor and where the national government is the sponsor of persecution by other State or nonState agents. As has usually been recognized, this is because there is no greater reason to entrust an applicant's protection to a government which persecutes indirectly than to one which persecutes directly.

When might it be possible to rebut the extremely strong presumption against IPA where the national government is the direct or indirect agent of persecution? The assertion that a person can be safe in an alternative region of the country when the national government is the agent or sponsor of persecution, absent the imposition

133 Singh v. Moschorak, above n. 130. See also, Damaize-Job v. INS, 787 F 2d 1332 at 1336 (9th Citcuit), 1986 , where the Court said, in relation to the contention that the Nicaraguan government persecuted Miskito Indians only on the Atlantic Coast:

[T]he record does not indicate any clear intent on the part of the Sandinistas to limit their persecution to any one geographical area, and Damaize testified that he can be readily identified as a Miskito wherever he goes.

134 Minister for Immigration and Multicultural Affairs v. Jang, (2000) 175 ALR 752 at 758-9. 
of a requirement that the person hide from the government, essentially presumes that relocation will fundamentally alter the person's relationship with the national government. This suggests an analogy to the Convention's cessation clause that allows refugee status to be withdrawn when 'the circumstances in connection with which he has been recognized as a refugee have ceased to exist. ${ }^{135}$ The test of whether a change of circumstances has taken place is an onerous one: the change must be proven to be substantial, truly effective, and durable. ${ }^{136} \mathrm{~A}$ comparably high burden should rest on the asylum State seeking to establish that a person who faces the risk of being persecuted by a national government can be said to be protected by that same government in the proposed IPA. ${ }^{137}$ In particular, once the national government has displayed an interest in persecuting an individual, it cannot be assumed that periods of non-persecution, even in a different location, are sufficient evidence that the government no longer intends to harm the applicant. This was recognized by a New Zealand tribunal in a case concerning a claim by a member of the All India Sikh Student Federation who had been tortured by Indian police:

It is common in such cases for police activity to be unpredictable and spasmodic, though their interest remains constant. It is a common feature of cases heard by the Authority that police will visit at irregular intervals. On occasion those intervals are closely spaced, on other occasions they-are widely spaced. For that reason care must be taken to ensure that inferences are drawn not only from the regularity of the visits, but also from the equally fundamental factor, namely the suspicions held by the police. ${ }^{138}$

There are, however, two 'intermediate categories' in which it is appropriate to apply a presumption against IPA, but not a nearly insurmountable presumption of the kind befitting situations of direct or indirect national government persecution.

The first intermediate category consists of cases where the threat is one that emanates from local governmental authorities. Because local governments operate under the authority of the national government, an IPA should be found to exist

1351951 Convention, Art. $1 \mathrm{C}(5)$.

136 UNHCR, Executive Committee, Conclusion No. 69 (XLIII) 1992, opines that the change in circumstances must be 'fundamental, stable and durable'.

137 US courts have generally recognized that the burden rests on the party seeking to rebut the presumption in cases involving State persecution. In a case involving a Coptic Christian from the Sudan whose family had been terrorized by government forces on religious grounds, the Court of Appeals for the 5 th Circuit held that:

[w] hen a party seeking asylum demonstrates that a national government is the 'persecutor', the burden should fall upon the INS to show that this government's persecutor', the burden should fall upon the INS to show that this government's
persecutive actions are truly limited to a clearly delineated and limited locality and situation, so that the applicant for asylum therefore need not fear a likelihood of persecution elsewhere in the nation.

Abdel-Masieh v. INS, 73 F 3d 579 at 587 (5th Circuit), 1996. 138 Re R.S., New Zealand RSAA, above n. 84. only very rarely in such a case. In principle, a national government that fails to intervene to prevent persecution by local authorities is highly unlikely to be a solid guardian of those who were victimized in that locality. Only if there is clear evidence that the persecuting authority has no sway outside its own region and that there were particularly extenuating circumstances to explain the national government's failure to counteract localized harms in the region of origin (of a kind not relevant to the proposed IPA) might it be possible to consider an IPA in such circumstances. A case in which the presumption may have been properly rebutted (but was not in fact considered) is Rakesh Maini, a recent decision of the US Court of Appeals for the Ninth Circuit. ${ }^{139}$ The decision involved the claim of a mixed Sikh-Hindu couple who were attacked by local Marxist party (CPM) operatives in Calcutta. As the CPM has no power in most other parts of India, the Court might reasonably have inquired into the possibility of internal protection.

On the whole, however, courts have properly taken a cautious approach to allegations that persecution is localized because the relevant action is by local authorities. For example, in Mirza v. Canada (Minister of Citizenship and Immigration), a Pakistani man applied for asylum in Canada because he feared persecution by local police based on his political activities. The police had raided a political meeting he had organized, and a local court issued an arrest warrant for him. The tribunal denied refugee status on internal protection grounds, finding that 'even if the arrest warrants were indeed valid, the panel, in light of the current country conditions, finds that the arrest warrants would not be acted upon'. The Federal Court overturned this finding, emphasizing that the arrest warrants could be executed anywhere in Pakistan, even if issued only by a local court. ${ }^{140}$

The second 'intermediate' category for which IPA may be relevant comprises cases where the national government has not supported the non-State agent of harm, but has simply tolerated its actions. While also operating under a presumption against the existence of an IPA, such cases may be more open to a rebuttal of the presumption since the conditions forming the basis of the government's decision to tolerate persecution in one region may not pertain to other regions of the country. For example, the extent of ethnic tension in a particular region may be so high that government intervention to protect an oppressed minority from vigilante thugs could legitimately be said to pose the risk of exacerbating widespread violence. In such circumstances, a government may decide that it has no practical option but to tolerate the abuse of a minority by non-State actors in a particular region at a particular moment. It may, however, be willing and able to protect that same minority in a different region in the country. Nonetheless, the instance of tolerance of privately inflicted persecution requires a careful inquiry as to the reasons

139 Rakesh Maini v. INS, 212 F 3d 1167 (9th Circuit), 2000.

140 Canadian Federal Court Trial Division, Decision No. IMM-4618-98 (1999); 1999 Fed. Ct. Trial Lexis 842 . 
for the government's actions, and suggests that caution should be exercised before finding the presumption rebutted.

C.

\section{Step 3: no new risk of being persecuted, or of refoulement, to the} region of origin

The third step in IPA analysis is to ensure that, by returning a person to an alternative region of their country of origin, the returning State is not simply substituting one predicament for another. The proposed IPA would clearly not offer protection if the risk of one form of persecution were obviated only to be replaced by a different risk of persecution for a Convention reason in the IPA. What of the situation, however, where there exists a risk of even generalized war or other violence in the proposed IPA (thus not qualifying an individual originating in the IPA to refugee status because there is no nexus to one of the five Convention grounds)? Or what if the only potential IPA were located in an uninhabitable desert (again, not sufficient to qualify an individual originating in the IPA to refugee status, as generalized hardship would not ordinarily amount to a risk of 'being persecuted')? Should an IPA be held to exist in either of these situations?

Jurisprudence in most States Parties suggests that, where the asylum seeker would confront either generalized harm within the realm of persecution or other forms of serious adversity, the existence of an IPA may be denied on the grounds of 'unreasonableness'. ${ }^{141}$ As recently explained by Brooke LJ in Karanakaran:

In theory it might be possible for someone to return to a desert region of his former country, populated only by camels and nomads, but the rigidity of the words 'is unable to avail himself of the protection of that country' has been tempered by a small amount of humanity. In the leading case of Exp. Robinson this court followed an earlier decision of the Federal Court of Canada and suggested that a person should be regarded as unable to avail himself of the protection of his home country if it would be unduly harsh to expect him to live there. ${ }^{142}$

141 See, e.g., the recent decision of the Full Court of the Federal Court of Australia in Perampalam $\mathrm{v}$ Minister for Immigration and Multicultural Affairs, above n. 114, in which the Court noted that:

It cannot be reasonable to expect a refugee to avoid persecution by moving into an area of grave danger, whether that danger arises from a persecution by moving into an a volcanic eruption), a civil war or some other cause. A well-founder (for example, a for a Convention reason having been other cause. A well-founded fear of persecution Convention reason behind every difficulty a refugee does not also have to show a Convention reason behind every difficulty or danger which makes some suggestion of
relocation unreasonable. Ibid., p. 284 per Burchett and Lee JJ.

142 See above n. 31, p. 456. See also, Randhawa v. Minister of Immigration, above n. 14; R. v. Secretary of [1997] 1 All [1997] 4 All ER 210; Adan v. Secretary of State for the Home Department, above n. 71.
However, as described in some detail in Section IV above, ${ }^{143}$ the risks of continuing to insist upon a consideration of these factors within the rubric of a 'reasonableness' inquiry are significant, including both inconsistency between and even within jurisdictions, and most importantly the imposition of a decision maker's perspective on appropriate behaviour in analyzing circumstances likely to be beyond his or her personal experience. As explained above, the 'reasonableness' inquiry is also extremely vulnerable to challenge or outright abrogation, since it appears to grant decision makers the right to engage in an open-ended humanitarian assessment of a kind not called for by the 1951 Convention itself. ${ }^{144}$ Rather than relying upon a vague term not found in the text of the 1951 Convention, the protection approach to IPA analysis requires that potential risks of a kind not capable of grounding an independent claim to refugee status be taken into account in ways that can more readily be accommodated within the 1951 Convention framework. This tack is not only more legally justified than the asserted duty to assess 'reasonableness', but as a pragmatic matter is more likely to be accepted by those adjudicators sceptical of the viability and justification of the amorphous reasonableness test. The relevance of generalized or non-persecutory serious harm in the IPA can be taken into account within the terms of the 1951 Convention in two ways.

First, it may be the case that the harm faced in the proposed IPA is sufficiently serious to fall within the realm of 'persecution', but nonetheless an insufficient basis for a refugee claim because it is truly generalized in its infliction or impact (that is, there is no nexus to one of the five Convention grounds). This might be the case if an applicant were exposed in the IPA to generalized threats to life or physical security associated with war, or to generalized extreme economic deprivation on a variety of fronts (for example, lack of food, shelter, or basic health care). While persons originating in the proposed IPA would fail the test for refugee status on nexus grounds, the same cannot be said of the person whose case is being considered on IPA grounds. The latter person did not face these (persecutory) risks in his or her place of origin, and has already been found to face a well-founded fear of being persecuted for a Convention reason in his or her home area. The only reason - albeit an indirect reason - that she or he now faces the prospect of a threat to life or physical security in the proposed IPA is therefore the flight from the place of origin on Convention grounds which has led him or her (via the asylum State) now to be confronted with a harm within the scope of persecution. The risk now faced is therefore a risk faced 'for reasons of' the Convention ground which initiated the original involuntary movement from the home region. This is because the nexus criterion in the refugee definition requires only a causal relationship between a protected factor (race, religion, nationality, political opinion, membership of a particular social group) and the persecutory risk. If the protected ground is a contributing

143 See the text above at nn. 95 et seq. 144 See the text above at nn. 108-10. 
factor to the risk of being persecuted, then Convention status is appropriately recognized. ${ }^{145}$

This is the position impliedly accepted in the German approach to IPA analysis. For example, the German Federal Administrative Court has explained:

[A]n alternative is not possible where the applicant would face threats elsewhere in his country of origin that are equivalent in intensity to those which initially led him to flee. Such threats need not be of a political nature; so long as the applicant would be forced into a precarious position to avoid... persecution ... in his region of origin, the applicant effectively has no access to an internal [protection] alternative. ${ }^{146}$

The alternative scenario presently addressed by 'reasonableness' analysis involves a risk in the IPA which is not sufficiently egregious to amount to a risk of 'being persecuted'. An independent refugee claim by a person originating in the IPA would therefore not, even if able to satisfy the nexus requirement, meet the definition of a Convention refugee. Yet serious harms falling short of persecutory conduct may nonetheless be relevant to the assessment of IPA. This is because a person under consideration for IPA has already prima facie satisfied the "well-founded fear of being persecuted' (inclusory) language of the 1951 Convention. The decision maker is now engaged in what amounts to an inquiry into exclusion from refugee status on the grounds that the applicant (like a person with an actual or de facto second nationality) does not in fact require surrogate international protection. In a fundamental sense, the question is whether the IPA can amount to an adequate substitute for the refugee status otherwise warranted in the asylum country. Critically, this inquiry is predicated on the fact that the person being considered for IPA has already been found to have a well-founded fear of being persecuted.

Because the IPA analysis amounts to an effort to identify a suitable in-country solution for a person known to face the risk of persecution in that same country, the decision maker is logically expected to engage in the same sort of analysis which would inform comparable exclusion inquiries. In the case of an individual

145 See J. C. Hathaway, 'The Michigan Guidelines on Nexus to a Convention Ground', 23(2) Michigan Journal of International Law, 2002, p. 207 and available on http://www.refugeecaselaw.org/ Refugee/guidelines2001.htm. Storey, above n. 35, p. 527, has argued for a similar approach (albeit in the context of the reasonableness approach):

To say that a risk of persecution in an IFA can be indirect entails recognising that, while the level of risk in one or more IFAs must be shown to be uniformly intense, the continuing directness of the cause of risk for a Convention reason need not. All that matters is that there continue to exist a serious possibility that conditions in the IFA would either re-expose the claimant to direct risk, cause the claimant to accept, or be forced to accept, undue hardship, or lead to a person becoming a victim of a violation of core fundamental human rights. 146 German Federal Administrative Court Decision No. BverwG C 45.92, 14 Dec. 1993 (unofficial
translation). possessed of actual or de facto nationality in a third State - the best comparator for the IPA analysis - account would clearly need to be taken of the duty of nonrefoulement. That is, an asylum State would be prohibited from denying refugee status on grounds of actual or de facto third (safe) State nationality if there were reason to believe that the conditions in the third State - while not themselves amounting to a direct risk of being persecuted - would nonetheless force the applicant back to his country of origin, thereby indirectly exposing the individual to the risk of being persecuted. Concern to avoid indirect refoulement underlies the text of Article 33(1) of the 1951 Convention, which provides: 'No Contracting State shall expel or return ("refouler") a refugee in any manner whatsoever to the frontiers of territories where his life or freedom would be threatened. ${ }^{, 147}$ The phrase 'in any manner whatsoever' is strongly indicative of the need for a broad rather than a narrow assessment of the applicant's predicament, focused on the particular concerns and circumstances of the individual applicant. ${ }^{148}$

Thus, if the conditions in the proposed IPA are such that this particular applicant may be compelled in fact to return to the area in which the risk of being persecuted exists rather than remain in the IPA, returning him or her to the IPA constitutes indirect refoulement. ${ }^{149}$ By directing IPA analysis to those factors that may drive this particular person back to the risk of persecution, asylum seekers gain the benefit of a focus on their specific physical, psychological, and social circumstances. In short, the inquiry is whether this applicant-given who he or she is, what he or she believes, and his or her essential make-up - would in fact be exposed to the risk of return to the place of origin if required to accept an IPA in lieu of his presumptive entitlement to asylum abroad. ${ }^{150}$

Critically, the assessment called for is not whether the decision maker believes that the conditions in the IPA are, in the decision maker's mind, sufficient to drive a 'reasonable' person back to the place of origin. Under 'reasonableness' analysis, an adjudicator might question why a person would ever return to a home region if she truly has a well-founded fear of being persecuted in that region and may thus be tempted to find the 'reasonableness' test satisfied even where there is a real chance that indirect refoulement will occur. By contrast, the IPA approach is premised on the notion that the decision maker's sole focus should be on whether this person is likely to be forced back to the dangerous region, regardless of what is 'reasonable' in

1471951 Convention, Art. 33(1) (emphasis added).

148 See e.g. J. C. Hathaway and J. A. Dent, Refugee Rights: Report on a Comparative Survey (York Lanes Press, Toronto, 1995), p. 6.

149 The invocation of the duty of non-refoulement in relation to the risk of being forced to move internally parallels the approach of the 'Guiding Principles on Internal Displacement', UN doc. E/CN.4/1998/53/Add.2, 11 Feb. 1998 (hereinafter 'IDP Guiding Principles'), at Principle 15(d): 'Internally displaced persons have... [t] he right to be protected against forcible return to or resettlement in any place where their life, safety, liberty and/or health would be at risk."

150 "Those characteristics do not matter because "of the opinion and feelings of the person concerned", but because of the risk they may cause': de Moffarts, above n. 30 . 
the circumstances. This approach therefore constrains the scope of decision makers to import their own subjective notions and assumptions of rational and appropriate behaviour into the determination process. This indirect refoulement analysis has been impliedly embraced, for example, by a German Administrative Court, which recognized that ' $[0]$ ne can, of course, see how it might logically be that strongly religious communities would feel compelled to risk persecution in order to return to a region of the country of origin in which they could practice their faith'..$^{151}$

It is clearly the case that the shift away from 'reasonableness' analysis in favour of consideration of both indirect nexus and indirect refoulement proposed here will, in many and perhaps most circumstances, yield a result which parallels that obtained under the 'reasonableness' approach. Indeed, the IPA approach has been criticized on the basis that it constitutes a reasonableness assessment 'by a different name'. ${ }^{152}$ For example, both methods of analysis acknowledge that an absence of well-founded fear of being persecuted in the IPA is insufficient to constitute meaningful protection. Even at the level of specific considerations, the range of factors that may be relevant to IPA indirect nexus or indirect refoulement analysis is large and includes some of the same factors as courts have taken into account in assessing 'reasonableness'. ${ }^{153}$ However at this point the similarity ends. Whereas reasonableness involves, as has been shown above, the decision maker's view of reasonable behaviour, ${ }^{154}$ the IPA approach concentrates on the reality of the conditions for the applicant - the so-called 'thin skull' rule familiar to tort lawyers. It appears that critics of the IPA approach have failed to grasp this fundamental distinction. ${ }^{155}$ Moreover, 'reasonableness' assessment is not a dependable basis for the protection of asylum seekers, ${ }^{156}$ since it is not anchored in a conceptual connection to the refugee definition. By contrast, a focus on either indirect nexus or the risk of indirect refoulement provides a structured, principled, and focused inquiry

151 Baden-Württemberg Administrative Court, Decision of 17 May 1990, A 12 S 533/89.

152 Massey, above n. 32, p. 9 . While criticizing the rejection of a 'reasonableness' criterion, nonetheless accepts the conceptual logic of the indirect of a 'reasonableness' criterion, Massey 153 The similarities in factors that may be considered in a reasoment approach.

with the 'indirect refoulement' inquiry bensidered in a reasonableness inquiry as compared with the 'indirect refoulement' inquiry were recognized in New Zealand RSAA, Decision
No. 71729/99, 22 June 2000, [2001] No. 71729/99, 22 June 2000, [2001] NZAR 183. However, that decision emphasized that there is no super-added reasonableness test, and that the significance of 'reasonableness' follows from its relevance to the issue of the availability of sufficient internal protection (ibid., at
paras. $75-6$ ).

154 See the text above at nn. 95-7.

155 For example, Massey attempts to apply this step of the Michigan approach by constructing a series of scenarios in which the risk in the IPA does not amount to persecution, but is nonetheless serious. He then asks whether the asylum seeker would have 'a greater chance of survival' in the original site than the proposed site in each of the scenarios, Massey, above n. 32, pp. 7-9. The Michigan approach, however, specifically eschews the notion of such a clinical objective weighing of relative risks, favouring instead an acknowledgment that the focus is on what this applicant is likely to do, whether or not it is adjudged 'rational' in the circumstances.

156 Interestingly, Massey appears to accept this criticism of the UNHCR approach. 'The [1999 UNHCR] Position Paper does not give any explanation how UNHCR approach. "The [1999 cant's personal profile] in particular, or the "reasonableness" test in general, enter into the assessment of well-founded fear': Massey, above n. 32, pp. 17-18. and is not at risk of being dismissed by courts as a 'humanitarian gloss' on the Convention text. Rather, it is required as a matter of international law.

\section{Step 4: minimum affirmative State protection available}

The fourth and most conceptually challenging element in the protection approach to devising a Convention-based IPA test gives content to the concept of 'protection'. If, as we believe, the only textually sound basis to require an at-risk person to accept an internal alternative to refugee status is that he or she can 'avail himself [or herself] of the protection of that country', then it is incumbent upon proponents of the IPA view to suggest just how the relevant 'protection' should be conceived.

The point of departure - acknowledged in the case law and by UNHCR - is that 'protection' is not simply the absence of the risk of being persecuted. That is, a person may not be at risk of persecution, yet simultaneously not be protected. The notion of 'protection' clearly implies the existence of some affirmative defence or safeguard. Yet once one moves beyond this truism, there is very little conceptual clarity as to the method by which the essential content of protection might be defined. One context-specific touchstone, however, is provided by the Preamble to the 1951 Convention in which it is noted that the key aim of the treaty is to 'revise and consolidate previous international agreements relating to the status of refugees and to extend the scope of and protection accorded by such instruments by means of a new agreement' (emphasis added). ${ }^{157}$ At the very least, then, 'protection' as conceived by the 1951 Convention includes legal rights of the kind stipulated in the Convention itself.

Some decisions rendered under the traditional 'reasonableness' framework have acknowledged the importance of legal rights to the assessment of internal protection alternatives. For example, cases involving child applicants have stressed the importance of access to education and basic economic subsistence. ${ }^{158}$ Moreover, in its Chahal decision, the European Court of Human Rights recognized the centrality

157 'The Convention and the Protocol represent a point of departure in considering the approptiate standard of treatment for refugees, often exceeded, but still at base proclaiming the fundamental principles of protection, without which no refugee can hope to attain a satisfactory and lasting solution to his or her plight': Goodwin-Gill, above n. 68, p. 296.

158 See e.g., Judgment of 24 March 1997, German Federal Constitutional Court, 2 BvR 1024/95, NVwZ 97, 65. In Elmi v Canada (Minister of Citizenship and Immigration), Canadian Federal Court (Trial 2 . Trial Lexis 220) the tribunal (Trial Divis ), Decision Somalia, on the ground that he could relocate within Somalia. The court overturned the decision out of concern for his ability to access education or employment:

What is merely inconvenient for an adult might constitute 'undue hardship' for a child ... In a case of a child whose education already has been disrupted by war, and who would arrive in Bossaso (IFA) without any money, the question arising is not simply of 'suitable employment', but of any livelihood at all. 
of these concerns to the IPA inquiry. In that case, the Court denied that the Sikh rity forces would had an IPA in India, in part because the Indian police and secumost directly, Lord Woolf includect his civil and political rights there. ${ }^{159}$ Perhaps mulation of the IPA test in the leading UK to human rights standards in his forHome Department and another, ex parte Robins decision of $R$. v. Secretary of State for the

In determining whether it would not be reasonable to expect the claimant to relocate internally, a decision-maker will have to consider all the claimant is entitled to the against the backcloth that the issue is whether the claimant is entitled to the status of refugee. Various tests have been meet basic norms of civil,.. (d) if the quality of the internal protection fails to as the last of these conside political and socio-economic human rights. So far Convention shows that the contions is concerned, the preamble to the principle that human beings should parties were concerned to uphold the without discrimination. 160 .6

Yet this fundamental rights approach has received too little judicial attention. It may be that decision makers fear that 'fundamental rights and freedoms' is an. unmanageably vague notion. proach travels considerably beyond the require be thought that a rights-based apThis point was implicitly mado in an Eneirements of the 1951 Convention text. Sri Lankan Tamil who argued that it English decision dealing with the claim of a to Sri Lanka. The Court affirmed the rejection unreasonable for him to be returned below, stating:

It would not seem to me necessary, in considering [the reasonableness test,... for decision makers] ... to conduct a wide-ranging inquiry into the quality of life which a returning applicant for asylum might expect to enjoy in the part of his home country to which it was proposed to return him. 161

The challenge, then, is to devise a principled approach which adumbrates the the 1951 Convention, but which cotection' compelled by the internal structure of the 1951 Convention, but which cannot be dismissed as simply a humanitarian opion to be adopted by more generous States.

The minimum acceptable level of legal rights inherent in the notion of requires a government normally to debate. It might be argued that 'protection' human rights in thent normally to be able to deliver all of the basic international be made, at a minimum, to the proposed protection. On this basis reference would be made, at a minimum, to the obligations contained in the International Covenant on Civil and Political Rights and the International Covenant on Economic, Social and Cultural Rights. More realistically, Hugo Storey posits that 'protection' ought not to be defined on the basis of absolute standards, but rather exists where there is no discrimination in the enjoyment of all basic human rights between persons returned on IPA grounds and others already resident in that place. ${ }^{162} \mathrm{~A}$ third alternative is suggested by the UN's 1998 'Guiding Principles on Internal Displacement', ${ }^{163}$ which combine the absolute and relative approaches. Guiding Principle 1 states:

Internally displaced persons shall enjoy, in full equality, the same rights and freedoms under international and domestic law as do other persons in their country. They shall not be discriminated against in the enjoyment of any rights and freedoms on the ground that they are internally displaced. ${ }^{164}$

Principles $10-30$ revert to a more absolute approach, requiring respect for a series of more detailed rights framed with specific reference to the dilemmas that confront persons who are - as are those excluded on IPA grounds - forced to relocate within their own country. There is therefore a logical appeal to defining the minimum standard of affirmative protection in the proposed IPA by reference to comparable norms.

Others, however, will argue that this approach risks going considerably beyond what the 1951 Convention requires. ${ }^{165}$ Specifically, if the failure to ensure any of these basic rights were to be deemed a sufficient basis to find an asylum applicant to be 'unprotected' in the proposed IPA site, an unwieldy disjuncture in the conceptualization of the refugee definition could arise. This is because there is no consensus that any risk to even a core, internationally protected human right is

162 Storey, above n. 29, pp. 5-11. 163 IDP Guiding Principles, above n. 149.

164 Ibid., Guiding Principle 1(1).

165 Professor R. Piotrowicz of the Department of Law, University of Wales, Aberystwyth, has made this argument quite clearly:

The main point of the Convention is to ensure that those who have nowhere else to go should not be sent to a territory where they are persecuted. If ... the State seeking to rely on the IPA/IFA/IRA cannot expect the asylum seeker to use the IPA/IFA/IRA in the absence of conditions that meet 'applicable human rights standards', even though the population at large in the relevant territory may not benefit from the rights referred to by these same 'applicable international human rights standards'. .. we would have a bituation asylum seekers but is not available to the rest of the population in the IPA/IRA/IFA. Furthermore, it may be
that, even if the level of human rights protection is not as good as it might be, nevertheless people in those areas are not being persecuted or having their rights breached for reasons envisaged in the Refugee Convention. If that is the case, why should it be relevant to the State seeking to rely on the IPA/IRA/IFA?

R. Piotrowicz, 'Comment on the Draft Summary Conclusions', 1 Oct. 2001 (on file with the authors). 
tantamount to a risk of 'being persecuted'. While first level human rights - the non-derogable civil and political rights (for example, freedom from torture) - are nearly universally so recognized, a more nuanced analysis of the relevance of second level (derogable civil and political) and third level (economic, social, and cultural) rights is required. Some, but not all, threats to these rights amount to a risk of 'being persecuted'. ${ }^{166}$ There will therefore clearly be situations in which protection would be granted on the basis of a risk inconsistent with the 'Guiding Principles' for example, lack of access to sanitation facilities, inability to receive a passport, absence of assistance in tracing relatives, or even confiscation of property - even though the risk of such harms would not normally entitle a person originating in the proposed IPA site to secure recognition of refugee status.

Because of this concern, the drafters of the IPA approach laid out in the 'Michigan Guidelines' determined that reference could instead be made to the rights which comprise the 1951 Convention's own definition of 'protection'. Since the rationale for IPA analysis is to determine whether an internal site may be regarded as affording a sufficient answer to the applicant's well-founded fear of being persecuted such that the presumptive remedy of protection in an asylum State is not required, then there is a logic to measuring the sufficiency of IPA 'protection' in relation to the actual protective duties of asylum States. ${ }^{167}$ The required standard is not respect for all human rights, but rather provision of the rights codified as the 1951 Convention's endogenous definition of 'protection' in Articles 2-33. In general terms these standards impose a duty of non-discrimination idents of the asylum country and refugecs in socio-economic rights ${ }^{168}$ including, for subset of civil and socio-economic rights, ${ }^{168}$ including, for example, freedom of religion, ${ }^{169}$ freedom

166 Hathaway, Refugee Status, above n. 4, pp. 105-24.

167 A comparable approach was taken in Lay Kon Tji v. Minister for Immigration and Ethnic Affairs, aboven, 54, in which the Federal Court of 'effective nationality' to an applicant from

[B]y the Refugee Convention those countries that do grant refugee status to an individual are also required to accord to the refugee freedom of religion (Article 4), to free access to local courts (Article 16). If (Article 15), and to permit the refugee to have confer those rights on the putative refuge country of second nationality would not must be afforded ton the putative refugee, being rights which by international law must be afforded to a national, it could hardly be supposed that it was intended law putative refugee must seek the protection of that state. The reason a putative refugee need not seek the protection of that state is because the nationality that the state offers
cannot be regarded as a truly effective nationality.

(Ibid., pp. 691-2).

168 See generally, J. C. Hathaway, 'The International Refugee Rights Regime', $8(2)$ Collected Regime').

1691951 Convention, Art. 4. of movement, ${ }^{170}$ access to courts, ${ }^{171}$ and rights to work, ${ }^{172}$ social assistance,,${ }^{173}$ and primary education. ${ }^{174}$

Reference to the 1951 Convention's internal standard of 'protection' has been criticized on the basis that there are difficulties with a literal application of Articles 2-33 to the internal protection analysis. ${ }^{175}$ This is certainly true to some extent, as the 1951 Convention's rights regime is tailored to counteract the disadvantages of involuntary alienage. ${ }^{176} \mathrm{It}$ is important to understand, however, that the IPA approach embraced by the 'Michigan Guidelines' does not suggest a literal application of Articles 2-33 in considering internal protection, but rather that decision makers seek inspiration from the kind of interests protected by these Articles as a way of defining an endogenous notion of affirmative protection in the refugee context. While in some ways falling somewhat short of the standard of 'protection' that would follow from assessment by reference to all key human rights or even to the 'Guiding Principles on Internal Displacement', the non-discrimination approach embodied in the 1951 Convention nonetheless provides a legally solid and contextualized assurance of durable protection. For example, the Canadian decision of Soosaipillai v. Canada (Minister of Citizenship and Immigration) - in which the Federal Court held that it would be 'unduly harsh' to require an elderly Tamil couple to seek protection in Colombo because ethnic discrimination would lead to difficulties in gaining access to the government services, which the frail applicants required ${ }^{177}$ could just as readily (and more legally justifiably) have been adjudicated in the claimants' favour on the basis of a protection-based understanding of IPA.

As this example makes clear, our point is not that the 'reasonableness' approach cannot generate positive protection results for asylum seekers whose cases are subject to internal protection analysis. To the contrary, in the hands of experienced and thoughtful decision makers, we believe the results will be largely the same. The difference, however, is that the greater analytical structure of IPA analysis and its more solid footing in international refugee law allow it more dependably to generate rightsregarding determinations of the reality of internal protection. By focusing on the provision of fundamental civil and socio-economic rights on a non-discriminatory basis - whether by reference to the whole spectrum of international human rights law, the 'Guiding Principles on Internal Displacement', or to the rights in the 1951 Convention itself - an understanding of 'protection' that is readily amenable to appellate and other accountability is established.

The final point to emphasize is that minimum affirmative State protection implies that there is a State in fact in control in the proposed IPA. This is not a notion

170 Ibid., Art. $26 . \quad 171$ Ibid., Art. $16 . \quad 172$ Ibid., Arts. 17, 18, 19, and 24.

173 Ibid., Arts. 20, 21, and 23. 174 Ibid., Art. 22.175 Massey, above n. 32, pp. 10-12. 176 Hathaway, 'Rights Regime', above n. 168.

177 Canadian Federal Court Trial Division, Decision No. IMM-4846-98 (1999); 1999 Fed. Ct. Trial Lexis 834 . 
free from controversy or from divergence in State practice. ${ }^{178}$ It is an extremely important issue, however, since lack of adherence to this principle has resulted in questionable applications of the internal protection principle. For example, some governments reject Iraqi Kurdish asylum seekers on the ground that they can relocate to one of the two Kurdish enclaves in northern Iraq. ${ }^{179}$ Similarly, some courts have held that Somali applicants can be returned to Somaliland or Puntland, even though no State structure is in place there. ${ }^{180}$ In cases involving Somali claimants in particular, such findings have frequently required applicants to turn to their own clan for protection. ${ }^{181}$ In one particularly worrying decision, the Spanish Supreme Court explicitly required the applicant to commit himself to joining one ethnic faction in order to obtain protection in holding that: 'Liberia is divided into territorial zones which are under the influence of different governments or authorities of the tribes or ethnic rivals, so that its citizens can avail themselves of the protection of the government they feel allied (related) to..182

The fundamental problem with such decisions is that none of the proposed protectors - whether it is ethnic leaders in Liberia, clans in Somalia, or embryonic local authorities in portions of northern Iraq - is positioned to deliver what Article $1 \mathrm{~A}(2)$

178 See e.g., de Moffarts, above n. 30:

The Geneva Convention does not specify what authority should give 'the protection of his country'. To be meaningful, protection does not necessarily have to be given by the central authority. It may also be [delegated to] a 'de facto' authority established on a part of the national territory [for] citizens having an effective link with this authority.

This approach does not, however, address the question of the international legal accountabilit of such a 'de facto authority', the critical concern from a protection perspective.

179 In Tawfik v. Canada (Minister of Employment and Immigration), [1993] FCJ 835, the Canadian Federal Court denied refugee status to a Turkish Kurd on the grounds that 'with some portion of northern Iraq under the de facto control of an elected Turkish government', an IPA existed. German courts have been somewhat in conflict on whether this approach is appropriate. While he Higher Administrative Court of nd 2 41/96) argued that nothern Iraq ang-Holsein Gudgmets and $2 \mathrm{~L} 41 / 96$ ) argued that northern Iraq cannot offer internal protection because there are no State-like structures there, the Federal Administrative Court (BverwG 9 C 17.98, 8 Dec. 1998) has disagreed, holding that the key question is whether a person would be targeted by Iraq agents: ELENA Research Paper, above n. 3, p. 35.

180 See e.g., the decision of the Canadian Federal Court (Trial Division) in Saidi v. Canada (Minister of Employment and Immigration), [1993] FCJ 932, in which refugee status was denied to a Somal applicant on the grounds that ' $h i s$ clan affiliation and its acceptance by the majority in the nort f the country' established an IPA. This is also the practice in Denmats ELENA Research Paper, above n. 3, p. 33 .

181 See e.g., the decisions of the Netherlands Rechtseenheidskamer (Law Unity Chamber), AWB 99/104, 3 June 1999; and AWB 99/73, 3 June 1999 (holding that the Mudug province in Somalia could be considered safe for members of the Darod and Hawiye clans which control much of the territory).

182 Decision of 19 June 1998: see ELENA Research Paper, above n. 3, p. 49. See also Zalzali v. Canada (Minister of Employment and Immigration), [1991] 3 FC 605, in which the Canadian Federal Court suggested, in the context of Lebanon, that there was a duty to seek the protection not only of one's national State, but also of 'an established authority' acting as a government. of the 1951 Convention requires, namely, the protection of a State accountable under international law. The protective obligations of the 1951 Convention in Articles 2-33 are specifically addressed to 'States'. The very structure of the 1951 Convention requires that protection will be provided not by some legally unaccountable entity with de facto control, but rather by a government capable of assuming and being held responsible under international law for its actions. In practical terms, the rights enumerated in the 1951 Convention similarly envisage that protection will be provided by an entity that has established, inter alia, a formal system for regulating aliens' social and economic rights, ${ }^{183}$ a legal and judicial system, ${ }^{184}$ and a mechanism for issuing identity and travel documents. ${ }^{185}$ Indeed, the fundamental premise that refugee protection is an inter-State system intended to deliver surrogate or substitute protection assumes the right of at-risk persons to access a legally accountable State - not just some (hopefully) sympathetic or friendly group - if and when the individual's own State fails fundamentally to protect his or her basic rights. There is simply no basis in law or principle to deviate from this foundational principle in the internal protection context.

\section{Procedural safeguards}

While procedural questions have been alluded to in the context of the substantive analysis presented above, we wish here to reiterate and draw together at least the most important issues of process in the internal protection context.

First, because IPA is defined in part by whether or not it can truly deliver an 'antidote' to the applicant's well-founded fear of being persecuted, ${ }^{\mathbf{1 8 6}}$ it follows necessarily that an IPA test should never be used in an accelerated procedure to deny refugee status before inquiring fully into the particular circumstances of an applicant. ${ }^{187}$ As explained above, the unfortunate practice of considering 'internal flight' as providing grounds for summary dismissal of a refugee claim is arguably logical if such considerations are (inaccurately) viewed as part of the basic 'wellfounded fear' inquiry. ${ }^{188}$ Under the protection approach, however, there can be no

1831951 Convention, Arts. 6, 17-19, and $21 . \quad 184$ Ibid., Arts. 12 and 16.

185 Ibid., Arts. 25, 27, and $28 . \quad 186$ See the text above at nn. 120 et seg.

$187 \mathrm{E}$.g. in Perampalam v. Minister for Immigration and Multicultural Affairs, above n. 114, the Full Court

of the Peral of the Federal Court of Austrila its application of the 'relocation principle', on the basis inter alia of its 'sparse findings' which
did not: engage in anything like an examination of the evidence to determine whether it would be reasonale to assume that the... extortion demands [of the Liberation Tigers of Tamil Eelam] would cease if the appellant moved a mere quarter of a mile away from her home to her daughter's home.

Ibid, p. 283 per Burchett and Lee JJ. 188 See the text above at nn. 41-8. 
question of internal protection being considered before the decision maker estabgion from which an applicant he well-founded fear of being persecuted in the reAppeals Authority:

Applications raising the issue of 'internal [protection] alternative' raise a number of complex questions, and no international consensus exists as to its precise relevance for the determination of refugee status. In most instances, it faced by the applicant is examination to establish whether the persecution protection is available in other limited to a specific area and that effective appropriate to consider other parts of the country. For this reason, it is not unfounded applications. ${ }^{189}$.

Secondly, it is extremely important that IPA be assessed in each individual case. ${ }^{190}$ Thus, decision makers should never apply generalized findings regarding 'safety' for whole ethnic or other groups in an IPA without considering the feasibilis vital that decision marticular individual whose application is being considered. It is vital that decision makers assess the prospects for each individual applicant in obeach particular case, rather than IIA, based on an assessment of the risk factors in of all members of a rather than on broad and general conclusions of the situation of all members of a particular group in the proposed IPA. ${ }^{191}$

An excellent example of the overriding importance of this principle is provided cerned an application for asylum by a Silkh in Bhambri v. Canada. ${ }^{192}$ That case conSikh militants, who for asylum by a Sikh man, suspected by police of supporting three occasions over the been arrested, beaten and tortured by the Indian police on days, and three weeks respectively. Bham months, for periods of seven days, twelve police. Following his fespectively. Bhambri had escaped each time by bribing the as to Bhambri's whereabouts, Bhambri occasions, designed to elicit information he lived with an aunt a medical doct fled to an unnamed region of India where (arested for

189 New Zealand RSAA, Decision No. 70951/98, above n. 47. According to the FLENA Resarch Paper, above n. 3, a number of European countries, including Spain to the ELENA Research eliminated IPA from a manifestly unfounded or accelerated procedures: see ibid., pp. 17
and 49 . 190 Accordingt

stances, not according to some blanket aph case should be decided on its particular circumclaimants.'

191 This is specifect

the north of Iraq cannot be an IPA for every rejected asylume, a Nethetlands court ruled that lands officials must examine each individual case in asylum seeker from Iraq; tather Netherhas sufficient ties with northern Iraq: Rechtseenheidskamer, 13 Sept. 1999, AWB $99 / 3380$. 192 Bhambri v. Canada (Minister of Citizenship and Immigration) 13 Sept. 1999, AWB 99/3380. Division), Decision No. IMM-649-96, [1996] FCJ 1661, 18 Dec. 1996. having treated a Sikh militant for a bullet wound, and Bhambri then fled India. The Federal Court nonetheless approved the Convention Refugee Determination Division's clearly insufficiently particularized finding:

Since the applicant was released from detention every time he was arrested, upon payment of a bribe, the Punjab police did not consider the applicant to be a terrorist or a supporter of terrorists... Sikhs can usually resettle elsewhere in India. This would most certainly be possible in the case of this applicant because he was not a member of any political organization, nor did he engage in anti-government activities. ${ }^{193}$

This result is highly questionable given the specific circumstances of this applicant's predicament. Even if it were true that 'Sikhs can usually resettle in India', it is dangerous to rely on such generalizations in lieu of assessment of the reality of an individual's case. ${ }^{194}$

Thirdly, the adoption of the protection approach necessarily implies, as described above, ${ }^{195}$ that the authorities of the asylum State have the evidentiary

193 Ibid.

194 This is often a problem in cases involving Sikhs from the Punjab and Tamils from the north of Sri Lanka. Although the Canadian Federal Court (Trial Division) has emphasized that the inquiry must be individualized and that there can be no generic determination of reasonableness (see Pathmakanthan v. Canada (Minister of Employment and Immigration), [1993] FCJ 1158), in practice both the Immigration and Refugee Board and the Court continue to apply general conclusions in individual cases. This can be seen in the approach to an application for asylum by a Punjabi farmer who had been forced to provide food, shelter, and transportation to Sikh militants. Following this activity he was arrested and detained by the Indian police, and was interrogated and 'badly tortured' by them. He managed to bribe his way out of prison and required six weeks of medical attention. He twice auted to live with relatives in other provinces, initially in Un Uttar Pradesh and then in Delhi. However, police inquiries and his family's concern regarding the police suspicion drove him back to Punjab, where he was again detained and tortured by the police. The Convention Refugee Determination Division (CRDD) rejected his asylum claim on IFA grounds and this rejection was affirmed on appeal to the Federal Court, where Gibson J explained:

On the facts before it, and, in particular, by reference to documentary evidence, the CRDD in this matter found there to be IFA destinations in India for Sikhs from the Punjab. The CRDD then turned to the second portion of the test, consideration of whether the IFA destinations, or any of them, would be reasonable for this Applicant on the circumstances of his individual claim ... I conclude that the CRDD applied the appropriate test in law in reaching the conclusion it did regarding an IFA for this particular applicant.

Dhaliwal v. Canada (Minister of Citizenship and Immigration), Federal Court of Canada (Trial Division), Decision No. IMM-1200-97 (1997); 1997 Fed. Ct. Trial Lexis 1408. Although acknowledging a role for an assessment of 'reasonableness' in the particular case, the CRDD's knowledging a role for an assessment of 'reasonableness' in the particular case, the CRDD's
decision (as approved by the Federal Court) gave short shrift to the particular circumstances of this case, preferring simply to adhere to its general view that Sikhs have an IPA in India. See also, Matter of R., above n. 33; and Australian RRT, Decision No. V96/04189, 26 Feb. 1997.

195 See the text above at n. 41 . 
burden of proof to establish a prima facie case that an IPA exists. ${ }^{196}$ This follows logically from the fact that before turning to a consideration of the possibility of an IPA, a decision maker is already satisfied that the applicant has established that he or she faces a well-founded fear of being persecuted for a Convention reason, thus giving rise to a presumptive entitlement to refugee status. When one considers that the responsibility for fact-finding is shared throughout the entire refugee status determination, ${ }^{197}$ it is vital that applications not be rejected based on an incorrect assumption that the applicant bears the onus of disproving every theoretical IPA site. The protection approach views an IPA inquiry as being akin to an exclusion inquiry, with the accompanying high degree of caution involved in finding that a sufficient degree of protection is available to obviate the need for protection under the Convention regime. The evidentiary responsibility on the asylum State to establish that an IPA exists extends to each of the four essential elements of the test of sufficiency of the IPA, namely, accessibility, antidote, no new risk of being persecuted or of indirect refoulement, and presence of affirmative protection. Once a prima facie case is presented, the asylum seeker may similarly rely upon any of these factors to rebut the assertion that an IPA exists. ${ }^{198}$

Finally and most fundamentally, procedural fairness must be accorded refugee applicants in the assessment of an IPA, as in relation to all aspects of refugee status determination. In the IPA context, this means that, at a minimum, the applicant must be given clear and adequate notice that the adjudicating authority intends to canvass the possibility of denying status on internal protection grounds. This includes notice as to the specific location which is proffered as an IPA, with adequate

196 C. Harvey, Seeking Asyltum in the UK: Problems and Prospects (Butterworths, London, 2000) pp. 280-1. There is, however, no universal agreement on this point. For example, the New Zealand RSAA has recently affirmed that the onus is on the refugee applicant to establish that
no IPA is available, although this finding no IPA is available, although this finding turned on the specific legislative provisions in New Even in these circumstances, the New Zealand RSAA, 22 June 2000, above n. 153, at para. 90 lished, the asylum State mes, the RSAA has made it clear that, once a prima facie case is established, the asylum State must give notice that an IPA is to be considered (unless this is obviou from the context of the case); Also, "the decision-maker has a legal obligation to disclose to the claimant any evidence relating to the internal protection alternative which the disclose to the intends to rely upon' (ibid., at para. 92). It has been suggested, however, the decision-maker sary inconsistency between the notion that the asylum seeker is chever, that there is no necesto prove his or her case, even as the authorities of the sylum is charged with the overall onus refugee status is made out - then assume the ovide asylum State - once a prima facie case for tion alternative. At this point, "it may be presumed, in the burden to show an internal protecthat the [risk of] persecution will continue'sumed, in the absence of evidence to the contrary, that the [risk of] persecution will continue': Justice D. Baragwanath, 'A Comment on Professor 197 '[W]hile the burden of proof in principle ro01, p. 7 (on file with authors).

ate all the relevant facts is in principle rests on the applicant, the duty to ascertain and evaluate all the relevant facts is shared between the applicant and the examiner': UNHCR, Handbook,
above n. 11, at para. 196 .

8 This is important to 196.

protection approach creates a set as one analyst has incorrectly concluded that the affirmative above n. 32, p. 12, n. 38 . opportunity to prepare a case in rebuttal. ${ }^{199}$ As the Canadian Federal Court has explained:

[I]n some cases the claimant may not have any personal knowledge of other areas of the country, but, in all likelihood, there is documentary evidence available and, in addition, the Minister will normally offer some evidence supporting the [IPA] if the issue is raised at the hearing.

On the other hand, there is an onus on the Minister and the Board to warn the claimant if an [IPA] is going to be raised. A refugee claimant enjoys the benefit of the principles of natural justice... A basic and well-established component of the right to be heard includes notice of the case to be met... The purpose of this notice is, in turn, to allow a person to prepare an adequate response to that case. This right to notice of the case against the claimant is acutely important where the claimant may be called upon to provide evidence to show that no valid [IPA] exists in response to an allegation by the Minister. Therefore, neither the Minister nor the [adjudicating tribunal] may spring the allegation of an [IPA] upon a complainant without notice that an [IPA] will be in issue at the hearing. ${ }^{200}$

\section{Conclusion}

Our analysis proposes the rejection of two extreme positions. On the one hand, it makes little sense to recognize the refugee status of an individual who truly can access meaningful domestic protection in a part of his or her country of origin, thereby avoiding the risk of being persecuted. In view of the fundamental surrogate protection purpose of international refugee law, there is no duty to admit as refugees those whose own government can be counted on to protect their basic rights in part, but not all, of the national territory. As refugees now frequently flee largely regionalized threats rather than monolithic aggressor States, the continuing viability of refugee law demands that account be taken of genuine opportunities for internal protection.

On the other hand, the specific approach taken in some States to assessment of internal protection possibilities often leaves much to be desired. Fundamentally, it is contrary to the ordinary meaning of words to insist that the existence of an internal

199 Some courts have specifically imposed this requirement. For example, the Canadian Federal Court of Appeal held that a claimant from Afghanistan could not be denied refugee status on IPA gronds un constituting an IPA: Rabbani v. Candda (Minister of Citizenship and Immigration), Canadian Federal Court (Trial Division), Decision No. IMM-236-96 (1997), 1997 Fed. Ct. Trial Lexis 681 . See also Austrian Administrative Court, Decision No.95/20/0295, 1996, in which the Court rejected an IPA for a Kurd from Turkey because the Minister failed to specify an exact IPA location. 200 Thirunavukkarasu v. Canada, above n. 25, pp. 595-6. 
protection option means that an asylum seeker does not have a 'well-founded fear of being persecuted'. Nobody would suggest, for example, that an individual at risk in Zurich, but who can find safety in Geneva, is not at risk in Switzerland. He or she is at risk in Switzerland, but can also find a remedy there. This common sense conceptualization of the issue can easily be accommodated by the structure of the 1951 Convention. Even a person who has a well-founded fear of being persecuted in the country of origin must also demonstrate that he or she 'is unable or, owing to such fear, is unwilling to avail himself [or herself] of the protection of that country'. If the applicant's own government is genuinely able and willing to protect him or her in a new location, this requirement is not satisfied, and refugee status may be denied. But because internal protection is considered only after the applicant has established a prima facie case of risk in his or her place of origin, internal protection is effectively treated as an issue of exclusion from refugee status in relation to which the government bears the evidentiary burden.

This is not a semantic or purely academic debate. As we have shown, the assessment of internal protection as part of the initial 'well-founded fear' analysis has frequently led to unwarranted denials of refugee status. In particular, treating internal protection as relevant to the initial case to be made by the asylum seeker has logically led some courts to impose a duty on the applicant to prove that no city, town, or village is safe for him or her, an approach rightly condemned by UNHCR as imposing an impossible evidentiary burden. Of even greater concern, locating internal protection analysis in the basic well-founded fear inquiry has provided a basis for the pre-emption of an analysis of risk in the place of origin altogether where internal protection appears to be plausible. Yet without a clear sense of the underlying risk, how can the sufficiency of countervailing internal protection truly be assessed? UNHCR's recent gloss on the 'well-founded fear' approach - namely, that there must be access to 'safety', and that it must be 'reasonable' to seek internal protection - has not remedied the problem. To the contrary, this standard has been relied upon by some decision makers to impose what amounts to a duty to hide (for example, by suppressing religious or political beliefs) in the country of origin, an approach patently at odds with the most basic goals of refugee law. The fungible notion of 'safety' (not a term found in the 1951 Convention) has also proved a dangerous distraction, leading some States to return applicants to face the risk of war and other serious dangers. While the harshness of this approach can be mitigated by judicious application of the 'reasonableness' criterion, in practice the inherent subjectivity of such an inquiry too often results in an ad hoc jurisprudence in which similarly situated persons are not similarly treated. And because there is no basis in the Refugee Convention to insist on the assessment of 'reasonableness', decision makers have understandably begun to question whether reasonableness should really be a part of the refugee status inquiry at all.

Our analysis here has therefore drawn together what we consider to be the best practice of courts around the world in a single, analytically clear approach, termed the 'internal protection alternative'. Firmly based on the text of the 1951 Convention itself, this standard is explicitly designed to realize the most basic goal of the Convention, namely, to identify as refugees only those persons who require the surrogate protection of refugee law because they do not have access to the protection of their own State. By undertaking the four fundamental inquiries outlined above - accessibility, antidote to the original well-founded fear, no new risk of being persecuted or of refoulement to the region of origin, and the presence of minimum affirmative State protection - we can ensure that protection is only denied on the basis of a clear understanding of both all risks, and all possibilities for meeting the asylum seeker's protection needs within the borders of his or her own country. So conceived, internal protection analysis is an inherent part of refugee status determination, effectively enabling $S$ tates to meet new protection challenges without risk of denying protection to persons who have no choice but to turn to the international community. 


\section{University Library}

\section{- M M N E R VA A gateway to Melbourne's research publications}

Minerva Access is the Institutional Repository of The University of Melbourne

\section{Author/s:}

Hathaway, James;FOSTER, MICHELLE

Title:

Internal Protection/ Relocation/ Flight Alternative as an Aspect of Refugee Status Determination

Date:

2003

Persistent Link:

http://hdl.handle.net/11343/25396 